\title{
Diferenciación cinética y morfológica de ettringitas mediante metakaolín, cementos Portland y el ensayo ASTM C 452-68. Parte II: diferenciación morfológica mediante análisis por SEM y DRX
}

\author{
Kinetic and morphological differentiation of ettringites in plain and \\ blended Portland cements with metakaolin and the ASTM C 452-68 test. \\ Part II: Morphological differentiation by SEM and XRD analysis
}

\begin{abstract}
Recepción/Received: 3-VIII-05
Aceptación/Accepted: 25-I-08

Publicado online/Online publishing: 23-II-09

\section{RESUMEN}

En esta Parte II se utilizaron los mismos materiales cementíceos (CPO, CPRS, y metakaolín, MK), los mismos cementos de mezcla y el mismo método de ensayo ASTM C 452-68 que en la Parte I. Otras determinaciones complementarias fueron: análisis químico de los materiales cementíceos, análisis por DRX y SEM de ettringitas y propiedades específicas de algunos cementos ensayados y de sus pastas.
\end{abstract}

R. Talero $^{*}$
Los resultados experimentales obtenidos han demostrado también que, el $7.0 \%$ de $\mathrm{SO}_{3}$ presente en los 30 cementos de mezcla con MK, ensayados conforme el método ASTM C 452-68, no se comporta como agresivo sino como "regulador de fraguado", porque los tiempos de fraguado y el aumento de resistencias mecánicas fueron como los de cualquier CP. De aquí que algunos de esos cementos de mezcla puedan ser considerados "cementos hidráulicos expansivos", el resto, no. Sin embargo, cuando la cantidad de yeso aportada fue el triple $\left(21,0 \% \mathrm{SO}_{3}\right)$, se comportó como agresivo, motivo por el cual ninguno de los referidos 30 cementos de mezcla pudo ser calificado de elevada ni moderada resistencia a los sulfatos. $Y$ en ambos caso, la ettringita de ambos orígenes estuvo implicada. Tanto cuando el resultado final de su comportamiento final fue beneficioso, como cuando fue nocivo.

Palabras clave: metakaolín, cementos Pórtland, ataque del yeso, ettringitas, velocidades de formación, tamaño.
SUMMARY

The same cementitious materials (OPCS, SRPCS and matekaolin, MK), the same blended cements and the same ASTM C 452-68 test than in Part I, were used. Other complementary determinations were: chemical analysis of cementing materials, SEM and XRD analysis of ettringites and specific properties of some cement tested and of their pastes.

The experimental results have also demonstrated that when $7.0 \% \mathrm{SO}_{3}$, equivalent to $15.05 \%$ of gypsum, was added to the $M$ pozzolan-containing Portland cement and tested with the ASTM C 452-68 method, it was not found to behave aggressively but rather as "setting regulator", because the increase in mechanical strengths over time and setting times in these mixes were, therefore, similar to the pattern observed in any PC. However, when the gypsum content was raised to triple than that amount $\left(21.0 \% \mathrm{SO}_{3}\right)$, it behaved aggressively. In both cases, logically, ettringite from both origins were involved in the resulting beneficial or adverse behavior.

Keywords: metakaolín, Portland cements, gypsum attack, ettringites, rates formation, size

(*) Instituto de Ciencias de la Construcción "Eduardo Torroja", CSIC (Madrid, España). 


\section{INTRODUCCIÓN}

La Parte I de este trabajo (1), ha estado dedicada al ataque de los sulfatos a cementos portland (CP) con metakaolín (MK o puzolana M), y más concretamente, a la diferenciación cinética de la ettringita de ambos orígenes, $M K$ y CP, mediante el método acelerado ASTM C 452-68 (2). Y para ello, se ha determinado la evolución del incremento de longitud, $\Delta \mathbf{L}(\%)$, de las probetas y del contenido de sulfatos de sus aguas de conservación, hasta la edad de 2 años. Los resultados experimentales que se obtuvieron de ambos parámetros confirmaron, una vez más, tras su análisis, estudio, discusión e interpretación, que al menos, después de las muy pocas horas de hidratación inicial de los PUZC $(C P+M K)$, la velocidad de formación, $\mathbf{V}_{\mathbf{f}}$, de la ettringita de origen alúmina reactiva, $\mathrm{Al}_{2} \mathrm{O}_{3}{ }^{\mathrm{r}-}$, (3), de las puzolanas es considerablemente mayor que la velocidad de formación de la ettringita de origen $\mathrm{C}_{3} \mathrm{~A}$ de los $\mathrm{CP}$ (4), lo que se verificó por la evolución durante todo el ensayo, del referido contenido de sulfatos de dichas aguas de conservación. Debido a ello, se propuso denominar a ambos tipos de ettringitas, ettringita de rápida formación, ett-rf, y ettringita de lenta formación, ett-If*, respectivamente.

Por otra parte, dichos resultados experimentales obtenidos demostraron también,

- que la formación conjunta de ett-rf y ett-If en un medio selenitoso común -las probetas ASTM C 45268 y RT: $\Delta \mathrm{L}$, en este caso, de los 30 cementos de mezcla con MK (PUZC)-, no tiene lugar de una forma independiente, sino inter-dependiente entre sí, es decir, ambas ettringitas se originan siempre en mayor o menor medida, debiendo ser el resultado final más cercano a la ett-rf que a la ett-If, cuando en el medio hay yeso y agua, pero especialmente, cuando más MK se ha añadido (40\%),

- que la superficie específica, los contenidos de $\mathrm{C}_{3} \mathrm{~S}(\%)$, $\mathrm{C}_{2} \mathrm{~S}(\%)$ y $\mathrm{C}_{3} \mathrm{~A}(\%)$ y los tiempos de fraguado, tienen una influencia considerable sobre la $\mathbf{V}_{\mathbf{f}}$ de la ett-TOTAL $=$ ett-T $=$ ettringita de origen $\mathrm{Al}_{2} \mathrm{O}_{3}{ }^{\mathrm{r}-}+$ ettringita de origen $\mathrm{C}_{3} \mathrm{~A} *$ del $\mathrm{CPO}$, y por consiguiente, sobre el parámetro $\Delta \mathbf{L}(\%)$ vs. tiempo determinado,

- que en la formación de las ettringitas, el símil del mecanismo topoquímico con disolución previa, TPQ, debe prevalecer sobre el de through solution, TS, y

- que la mayor parte de la alúmina presente en el MK debe ser considerada reactiva, lo cual está de acuerdo con la $4^{a}$ conclusión de un artículo previo ya publicado (7); esta conclusión no puede ser aplicada sin más, a

* Ettringita que se forma más lentamente, del $\mathrm{C}_{3} \mathrm{~A}$ presente en los CPO, después de su hidratación inicial; no se intenta que el término ett-If signifique que este tipo de ettringita sea siempre un producto de reacción de lenta formación, cuando co-precipita con ett-rf (5)(7-10), sino únicamente que en esta última circunstancia, se forma del $\mathrm{C}_{3} \mathrm{~A}(\%)$ de los $\mathrm{CPO}$.

\section{INTRODUCTION}

Part I of this study (1) dealt with sulphate attack on Portland cement (PC) - metakaolin (MK or M pozzolan) blends, and more specifically with the kinetic differentiation of ettringite from these two origins, MK and PC, found by monitoring the percentage increase in specimens length, $\Delta L(\%)$, and the sulphate content in their curing water over a two-year period when exposed to the test set out in ASTM C 452-68 (2). The analysis of the experimental results obtained for both parameters re-confirmed that at least in the first few hours of POZC $(P C+M K)$, hydration, the formation rate for ettringita from reactive alumina, $\mathrm{Al}_{2} \mathrm{O}_{3}{ }^{r-}$, (3) present in pozzolans was consider-ably higher than the formation rate for ettringite originating in the $C_{3} A$ present in the $P C$ (4). This was verified throughout the test by the sulphate content in the afore-mentioned curing water. In light of the foregoing, the denomination proposed for these two types of ettringite was: rapid forming ettringite or ett-rf, and slow forming ettringite or ett-If*.

Furthermore, the experimental results showed that:

- in an ordinary gypsum-bearing medium (defined in ASTM C 452-68 and RT: $L L$, in which specimens made with 30 MK-containing blended cements (POZCS) were immersed), the joint formation of ett-rf and ett. -If did not take place separately, but rather interdependently. In other words, the two ettringites always appeared to a greater or lesser extent, with the final reaction product closer to ett-rf than ett-If in the presence of sulphates and water, especially when the highest proportion of MK was added (40\%);

- specific surface, $C_{3} S(\%), C_{2} S(\%)$ and $C_{3} A(\%)$ contents and setting times had a considerable impact on the $V_{f}$ of ett-TOTAL = ett- $T$ = ettringite from $\mathrm{Al}_{2} \mathrm{O}_{3}{ }^{r-}+$ ettringite from the $\mathrm{C}_{3} A^{*}$ present in the OPC and, therefore, on $\Delta L(\%)$ vs time;

- in ettringite formation the topochemical mechanism, $T P Q$, with prior dissolution, must prevail over TS, the through solution pathway; and

- pursuant to the 4th conclusion of the prior paper referenced (7), most of the alumina present in the $M K$, unlike the salt existing in any other natural or

* Ettringite from the $C_{3} A$ present in the OPC that forms more slowly after initial hydration; the intention is not for the term ett-If to mean that this type of ettringites is always a slow forming reaction product when it co-precipitates with ett-rf (5)(7-10), but simply that under such circumstances, it is formed from the $C_{3} A(\%)$ present in the OPCS. 
ninguna de las demás puzolanas artificiales -cenizas volantes, principalmente-, ni naturales.

Como se recordará, la formación de ettringita de origen $\mathrm{C}_{3} \mathrm{~A}$ de los CP fue verificada mediante trabajos previos (4-11); igualmente se demostró también que las adiciones puzolánicas forman también ettringita como consecuencia de su exposición al mismo medio agresivo sulfático (del yeso) (4-11). El desacuerdo de algunos investigadores sobre el efecto de las puzolanas en la cinetoquímica y morfología de la ettringita, nos obligó una vez más a tener que usar un nuevo ensayo para confirmar los resultados obtenidos en ensayos anteriores realizados mediante DRX (4) y el método Le Chatelier-Ansttet (5-10). Por ese motivo, el ensayo ASTM C 452-68 $(1)(5,6)(10,11)$ se aplicó a cementos Portland ordinarios (CPO), a cementos Portland resistentes a los sulfatos (CPRS) y a sus cementos PUZC con MK, para obtener durante 2 años los valores de ambos parámetros: el físico o $\Delta \mathbf{L}(\%)$ de las probetas y el químico o contenido de sulfatos de sus aguas de conservación durante todo ese tiempo, cuyo análisis, estudio, discusión e interpretación, condujo mediante 20 hipótesis de comportamiento (2 de ellas, en contrario), razones esgrimidas y/o pruebas aportadas, a la obtención de las conclusiones anteriores.

No obstante lo cual, es posible que alguno(s) de los referidos investigadores tenga(n) ciertas dudas todavía. Por este motivo, en esta Parte II se van a aportar las hipótesis de comportamiento, razones y pruebas definitivas para que les desaparezcan tales dudas.

Además, como consecuencia de la cuestión que se planteó al final de otro artículo anterior nuestro (9), relativa a la posibilidad de que cantidades más pequeñas de yeso agresivo que la usada en el ensayo Le Chateklier-Ansttet ( $\approx 33 \%$ en peso), podían ser usadas sin peligro, para confirmarlo, se ha utilizado la cantidad de yeso que se le ha de aportar al cemento que se ensaye mediante el método ASTM C 452-68 ( $\approx 15,05 \%$ en peso $\left.=7,0 \% \mathrm{SO}_{3}\right)$. Para ello, se prepararon 30 PUZC con $10 \mathrm{CP}-6 \mathrm{CPO}$ y 4 CPRS- mezclados con 20, 30 y $40 \%$ de MK en las siguientes proporciones de mezcla: CPO-no o CPRS-no/M $80 \% / 20 \%$, $70 \% / 30 \%$ y $60 \% / 40 \%$, respectivamente.

\section{OBJETIVOS}

Los principales objetivos de esta Parte II de la investigación son los siguientes:

1. Confirmar una vez más en primer lugar, mediante el ensayo ASTM C 452 68, que la velocidad de formación, $\mathbf{V}_{\mathbf{f}}$, de la ett-rf tiene que ser mayor que la $\mathbf{V}_{\mathbf{f}}$ de la ettIf, $y$, en segundo lugar, verificarlo mediante SEM y DRX.

2. Determinar la relación de tamaños de ambas ettringitas. Al menos, de forma comparativa o aproximada. artificial (primarily fly ash) pozzolan, must be regarded to be reactive.

The formation of ettringite from the $C_{3} A$ present in $P C$ had been verified in preceding papers (4-11), where it was likewise shown that pozzolanic additions also form ettringite when exposed to an aggressive sulphate medium (gypsum in this case) (4-11). The objections of some researchers to the findings on the effect of pozzolans on ettringite kinetochemistry and morphology have led to further testing to confirm the results obtained in preceding XRD (4) and Le Chatelier-Ansttet (5-10) trials. To this end, the ASTM C 452-68 test $(1)(5,6)(10,11)$ was applied to ordinary Portland cements (OPCs), sulphate-resistant Portland cements (SRPCS) and their blends with MK (POZC) to obtain the values for two parameters over a two-year period: a physical parameter, namely specimen expansion $(\Delta L(\%))$ and a chemical parameter, the sulphate content in the curing water over the same period. The analysis of the results and a study of 20 behavioural hypotheses (two opposing), explanations and/or evidence, led to the foregoing conclusions.

That notwithstanding, some of the above-mentioned researchers may still harbour certain doubts. With that in mind, this Part II aims to lay down conclusive behavioural hypotheses, explanations and evidence to dispel such doubts.

Moreover, to confirm the possibility posed at the end of an earlier article (9) to the effect that smaller amounts of aggressive gypsum than used in the Le ChatelierAnstett test ( $\approx 33$ mass \%) might be safely used, the amount of gypsum added was the amount specified in ASTM C 452-68 for addition to cement $(\approx 15,05$ mass $\%=7,0$ mass $\%$ of $\mathrm{SO}_{3}$ ). To this end, 30 POZCs were prepared by blending ten PCS - six OPCs and four SRPCS - with 20, 30 and $40 \%$ of $M K$, as follows: OPCNo. or SRPC No./M 80\%/20\%; 70/30\% and 60\%/40\%, respectively.

\section{OBJECTIVES}

The chief objectives of this Part II of the study were as follows:

1. Firstly, to re-confirm, using the ASTM C 452-68 test, that the formation rate $\left(V_{f}\right)$ of ett-rf must be higher than the ett-If rate, and secondly, to verify this finding with SEM and XRD.

2. To determine the crystal size ratios of the two ettringites, at least comparatively or approximately. 
3. Determinar si el comportamiento de la cantidad de yeso de los 30 PUZC ensayados conforme el método ASTM C 452-68, es en realidad agresivo o no, y sus consecuencias posibles.

4. Determinar el grado de ataque relativo del yeso a cada PUZC con MK, de acuerdo con los ensayos ASTM C 45268 y RT: $\Delta \mathrm{L}$ y sus respectivas especificaciones $(5,6)(11)$.

\section{PARTE EXPERIMENTAL}

3.1. Materiales de partida. De acuerdo con el diagrama ternario de Eitel (12), se eligieron los siguientes materiales de partida cuya composición química y otras propiedades físicas se encuentran en la Tabla 1:

1. 6 CPO -P-1, P-2, P-4, P-32, P-31 y P-5 -, y 4 CPRS PY-5, PY-1, PY-4 y PY-6-.
3. To determine whether the amount of gypsum added to the 30 POZCs tested under ASTM C452-68 was actually aggressive, and the possible implications.

4. To determine the degree of relative gypsum attack on each POZC / MK blend, pursuant to the ASTM C 45268 and $R T: \Delta L$ tests and their respective specifications $(5,6)(11)$.

\section{EXPERIMENTAL}

3.1. Starting material. The starting materials, listed below, were chosen in accordance with Eitel's (12) ternary diagram. Their chemical composition and physical properties are given in Table 1.

1. 6 OPCS: P-1, P-2, P-4, P-32, P-31, P-5; and 4 SRPCS: $P Y-5, P Y-1, P Y-4, P Y-6$.

Tabla 1 / Table 1

Determinaciones Químico-Físicas.

Physical-Chemical calculations.

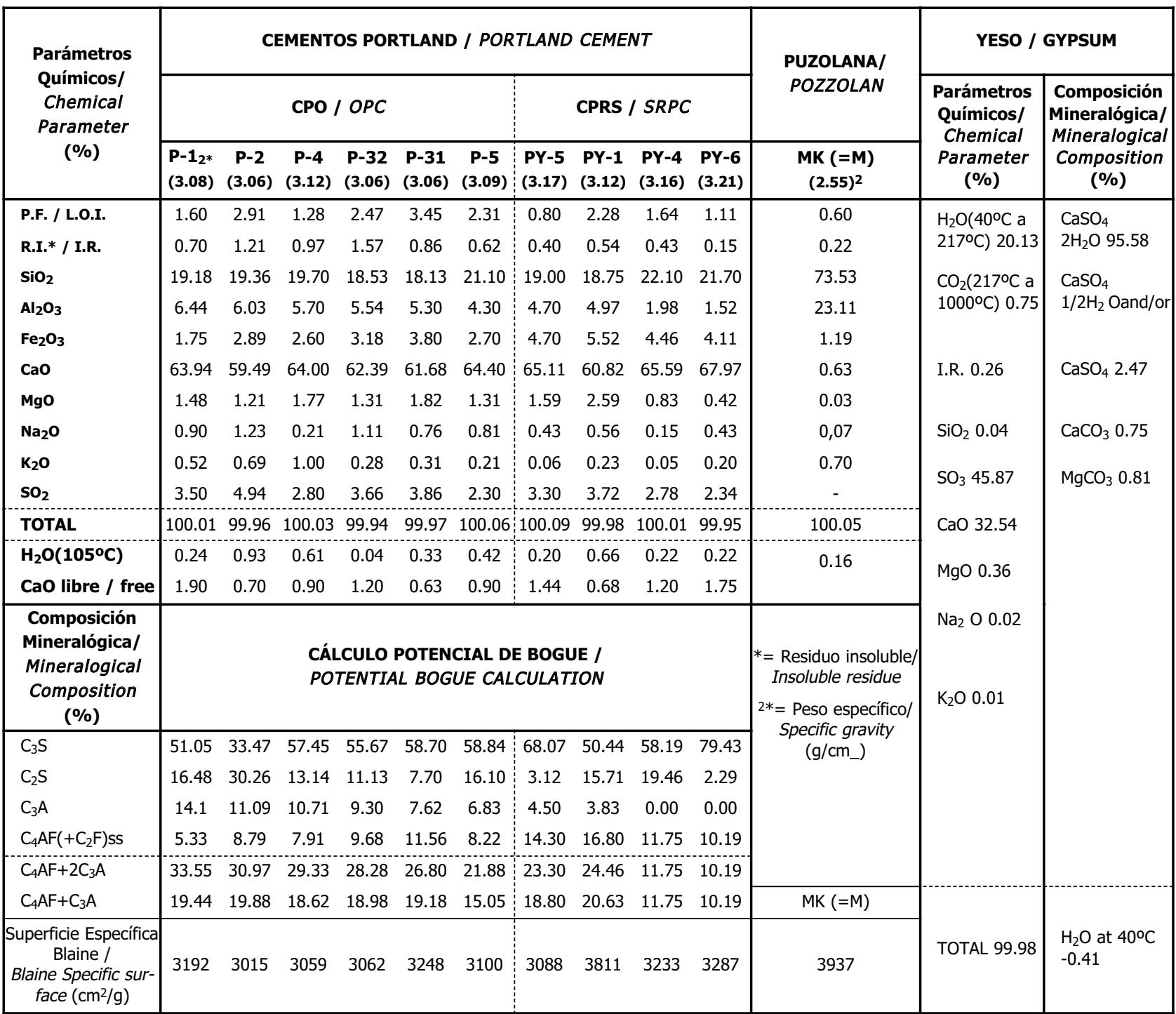


2. Metakaolín (= MK o puzolana M) que se preparó calcinando caolín (con $\approx 50 \%$ de cuarzo) a $750{ }^{\circ} \mathrm{C}$ siendo su especificación granulométrica la de la norma ASTM C 595-95 (13) (cantidad máxima retenida en el tamiz de $45 \mu \mathrm{m}$, mediante tamizado húmedo, 20\%).

3. Yeso: se utilizó como agresivo piedra de yeso natural, con un elevado contenido de $\mathrm{CaSO}_{4} .2 \mathrm{H}_{2} \mathrm{O}$ (Tabla 1 ).

\subsection{Procedimiento experimental}

En primer lugar, se prepararon los 30 cementos de mezcla (PUZC), con $10 \mathrm{CP}-6 \mathrm{CPO}$ y 4 CPRS- y MK, en las proporciones porcentuales de mezcla $80 \% / 20 \%$ (= $80 / 20), 70 \% / 30 \%(=70 / 30)$ y $60 \% / 40 \%(=60 / 40)$ (en masa). La mezcla 100\%/00\% (=100/00), corresponde al CPO $\left(=\mathrm{P}-\mathrm{n}^{\circ}\right)$ y al SRPC $\left(=\mathrm{PY}-\mathrm{n}^{\circ}\right)$ puros.

En segundo lugar, todos estos PUZC fueron analizados mediante el ensayo de Frattini (14), con el fin de confirmar químicamente, sus características puzolánicas a 28 y/o 7 días, más tarde relacionada con el ataque de los sulfatos, ver Tabla 2 y el resto de valores a 7 y 28 días, en la Figura 1.
2. Metakaolin (=MK or M pozzolan) prepared by calcining kaolin (with $\approx 50 \%$ quartz) at $750^{\circ} \mathrm{C}$. Its grain size distribution was as specified in ASTM C 595-95 (13) (maximum $20 \%$ retained in a $45-\mu m$ sieve during moist sieving).

3. Gypsum: natural gypsum with a high $\mathrm{CaSO}_{4} 2 \mathrm{H}_{2} \mathrm{O}$ content was used as the aggressive agent (Table 1 ).

\subsection{Operating procedure}

First, 30 blended cements (POZC) were prepared with ten PCS (six OPCS and four SRPCS) and MK in the following proportions: $80 \% / 20 \% \quad(=80 / 20) ; 70 \% / 30 \%$ $(=70 / 30)$ and $60 \% / 40 \%(=60 / 40)$ (by weight). The $100 \% / 00 \%(=100 / 00)$ blends contained pure OPC $(=P$ No.) or SRPC (=PY-No.).

Secondly, all these POZCs were analyzed with the Frattini test (14) to chemically confirm their 28- and 7-day pozzolanicity, later to be related to sulphate attack (see Table 2) and the rest of the 7- and 28-day values in Figure 1.
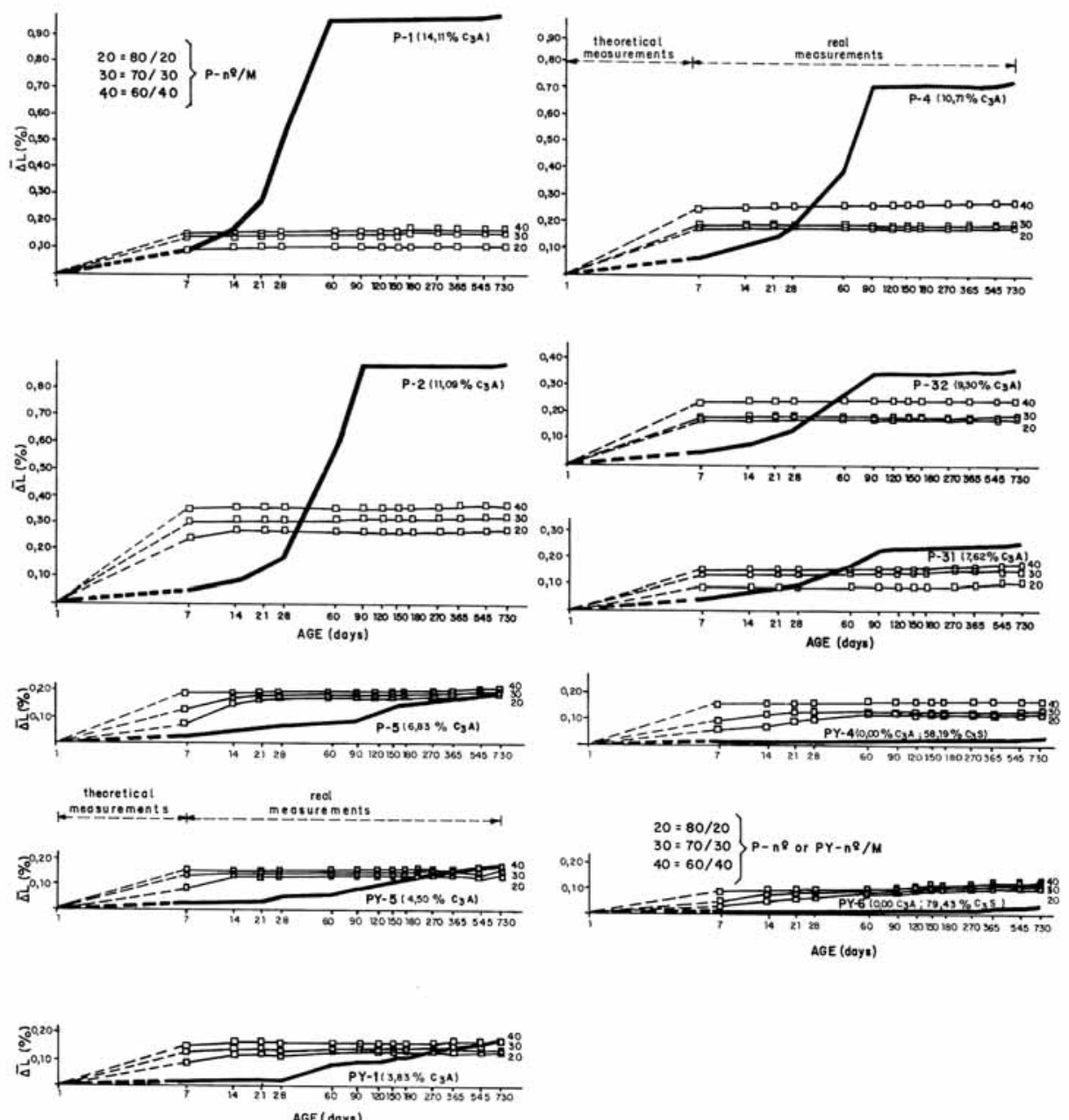

AGE (daya)

Figura 1 / Figure 1. Morteros/Mortars: ASTM C 452-68 tipo/type; Probetas/Specimens: 1"x1"x111/4"; Parámetro/Parameter: $\Delta \mathrm{L}(\%)$ vs tiempo/time; Cementos/Cements: 6 CPO/OPC, 4 CPRS/SRPC y/and 30 /PUZC/POZC con/with M puzolana/pozzolan. 
Tabla 2 / Table 2

Puzolanicidad (ensayo de Frattini): resultados a 2 días. Two-day pozzolanicity (Frattini test).

\begin{tabular}{|c|c|c|c|c|c|c|c|c|}
\hline \multirow{3}{*}{$\begin{array}{c}\text { Cementos / } \\
\text { Cement }\end{array}$} & \multicolumn{8}{|c|}{ Ensayo de Frattini: resultados a 2 días / Frattini test: 2-day results } \\
\hline & \multicolumn{4}{|c|}{ sin / without $7.0 \% \mathrm{SO}_{3}$} & \multicolumn{4}{|c|}{ con / with $7.0 \% \mathrm{SO}_{3}$} \\
\hline & $*$ & {$\left[\mathrm{OH}^{-}\right]$} & $*$ & [CaO $]$ & $*$ & {$\left[\mathrm{OH}^{-}\right]$} & * & [CaO] \\
\hline \multicolumn{9}{|l|}{ P-1 100/00 } \\
\hline P-1/M 80/20 & 58.00 & 55.00 & 6.08 & 6.35 & 40.80 & 59.00 & 18.20 & 6.00 \\
\hline P-1/M 70/30 & 50.75 & 48.50 & 5.32 & $\mathbf{5 . 5 0}$ & 35.70 & 49.50 & 15.93 & 5.55 \\
\hline P-1/M 60/40 & 43.50 & 35.00 & 4.56 & 2.15 & 30.60 & 44.50 & 13.65 & 5.45 \\
\hline PY-6 100/00 & & 42.50 & & 21.50 & & 42.50 & & 31.10 \\
\hline PY-6/M 80/20 & 34.00 & 41.00 & 17.20 & 16.60 & 34.00 & 33.00 & 24.88 & 26.50 \\
\hline PY-6/M 70/30 & 29.75 & 34.50 & 15.05 & 13.50 & 29.75 & 30.00 & 21.77 & 25.00 \\
\hline PY-6/M 60/40 & 25.50 & 28.00 & 12.90 & 11.15 & 25.50 & 25.50 & 18.66 & 18.50 \\
\hline \multicolumn{9}{|c|}{$\begin{array}{l}\text { NOTAS / NOTES: } \\
\text { * Valores asumiendo que el metakaolín es inerte / Values assuming metakaolin to be inert. } \\
\text { 1. Las parejas de valores en negrita significa que los puntos se encuentran en la región de subsaturación (= + result) / Pairs of values in bold indi- } \\
\text { cate that the point is in the subsaturation region }(=+ \text { result). } \\
\text { 2. El resto de PUZC mostraron valores del mismo orden de magnitud para cada parámetro químico / All other POZCs exhibited values of a similar order } \\
\text { of magnitude for each chemical parameter. }\end{array}$} \\
\hline
\end{tabular}

En tercer lugar, cada PC y PUZC fue sometido al ensayo ASTM C 452-68 ( $\mathrm{y}$ adicionalmente, también al ensayo $\mathrm{RT}$ : $\Delta \mathrm{L}(5,6)(11)$ cuando fue necesario; este ensayo es similar al ASTM C 452-68, pero con $21,0 \%$ de $\mathrm{SO}_{3}$ en lugar de $7,0 \%$ de $\mathrm{SO}_{3}$ ). De cada $\mathrm{CP}$ y PUZC se fabricaron 4 probetas $\left(1^{\prime \prime} x 1^{\prime \prime} \times 11^{\left.1 / 4^{\prime \prime}\right)}\right.$ solamente, a las que se les determinó el parámetro incremento porcentual de longitud, $\Delta \mathbf{L}(\%)$ (Figura 1), y tres probetas más en caso necesario, para ratificar algún valor previo obtenido que fuera dudoso (la cantidad de mortero sobrante fue prácticamente la misma siempre). La longitud de las probetas se midió a $1,7,14,28,69,90$ días, $\Delta \mathbf{L}_{\mathbf{x d}}(\%)$, o aún más tarde, hasta 2 años, dependiendo del propósito. La cantidad de mortero sobrante y la cantidad de mortero de la $4^{a}$ probeta, se utilizó para fabricar pequeñas probetas $(1 \times 1 \times 6 \mathrm{~cm})$ adicionales a las que se les determinó en paralelo su RMF y su RMC a las mismas edades anteriores.

Finalmente, a algunos CP y a sus PUZC con MK, se les determinó también las resistencias mecánicas (a flexión, RMF, y a compresión, RMC) (15) (Tabla 3), la cantidad de agua de consistencia normal, la estabilidad de volumen (Agujas de Le Chatelier ) y los tiempos de fraguado (16) (Tabla 4).

La razón del volumen de agua de conservación, al volumen de las 3 probetas de $1^{\prime \prime} \times 11^{\prime \prime} \times 11^{1} / 4^{\prime \prime}$, fue siempre el mismo -no excediendo de 5 a 1 (2)-, y la de las probetas pequeñas $(1 \times 1 \times 6 \mathrm{~cm})$, y el resto de probetas, también.

Otras determinaciones complementarias o necesarias incluidas fueron: análisis químico de los materiales cementíceos utilizados, propiedades químicas y físicas específicas de algunos cementos ensayados (Tabla 1) y análisis mediante SEM y DRX (Figuras 2(a), 2(b),
Thirdly, each PC and its POZC was tested with the ASTM C 452-68 and, wherever necessary, with the RT: $\Delta L$ method $(5,6)(11))$; this latter test is similar to ASTM C452-68, but uses $21,0 \%$ instead of $7,0 \% \mathrm{SO}_{3}$. Four $\left(1^{\prime \prime} x 1^{\prime \prime} x 11\right.$ ?") specimens were made from each $P C$ and $P O Z C$ to determine their percentage length increase, $\Delta L(\%)$ (Figure 1); where necessary, three further specimens were made to clarify dubious findings (the amount of remaining mortar was nearly always the same). Specimen length was measured after $1,7,14,28,69$, and 90 days $\left(\Delta L_{x d}(\%)\right)$ or even longer intervals, up to two years, depending on the purpose. The remaining mortar and the mortar reserved for the fourth specimen were used to make smaller additional specimens $(1 \times 1 \times 6 \mathrm{~cm})$, whose compressive (MS-C) and bending (MS-B) strengths were also determined at the above ages.

Finally, some of the PCs and MK-bearing POZCs were tested for the water needed to reach normal consistency, volume stability (Le Chatelier needles) and setting times (16) (Table 4), in addition to mechanical strength (15) (Table 3).

The ratio of the volume of curing water to the volume of the three 1 "x1"x11?" specimens, as well as to all other specimens, was constant and never over 5 to 1 (2).

Other parameters studied included: chemical analysis of the cementitious materials used and specific properties of some of the cements tested (Table 1) as well as SEM (Figures 2(a), 2(b), 2(c), 3(a), 3(b) and 3(c))2) and XRD analyses (Figures 4 and 5) of 


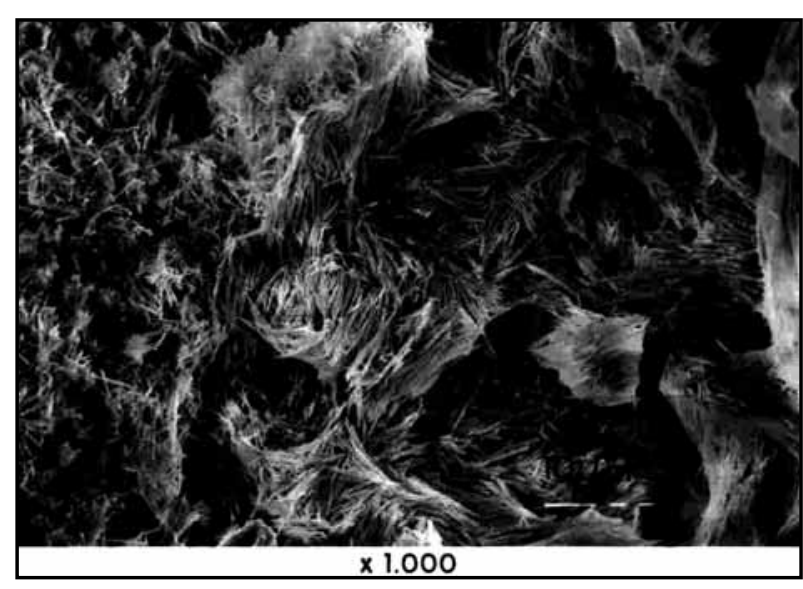

Figura 2(a). Ettringitas de "rápida" formación. Figure 2(a). Rapid forming ettringite (ett-rf).

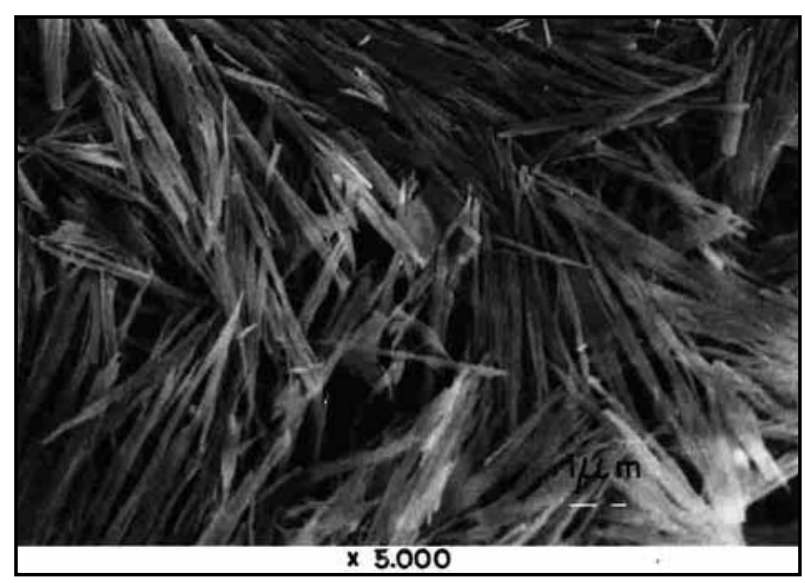

Figura 2(b). Ettringitas de "rápida" formación. Figure 2(b). Rapid-forming ettringites (ett-rf).

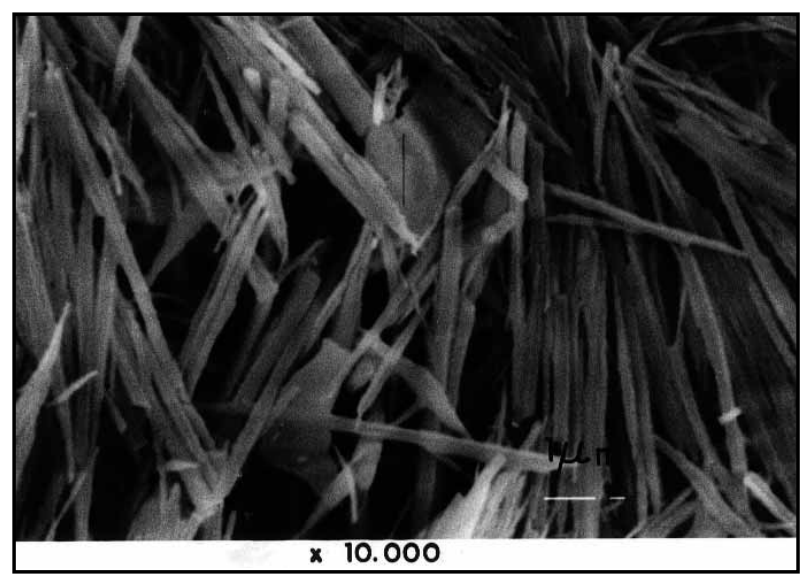

Figura 2(c). Ettringitas de "rápida" formación. Figure 2(c). Rapid forming ettringites (ett-rf).

2(c), 3(a), 3(b) y 3(c)) y DRX (Figuras 4 y 5) de las ettringitas. Estos dos últimos análisis se realizaron tomando $20 \mathrm{~g}$ de cada CP ó PUZC (con 33,33\% de yeso en lugar de $15,05 \%$ ), los cuales fueron conservados también en la correspondiente cantidad de agua, después de haber fraguado con mucha lentitud, lógicamente.

\section{RESULTADOS, DISCUSIÓN E INTERPRETACIÓN}

Para la discusión e interpretación de los valores experimentales obtenidos de $\Delta \mathbf{L}(\%)$, las curvas de la Figura 1 se dividieron en dos grupos de curvas diferentes:

(ao) Grupo de curvas cóncavas (de línea continua y gruesa en la Figura 1) con diferente valores del $\Delta \mathbf{L}_{\mathbf{7 d}}(\%)$ y edad del fin de su concavidad, a partir de la cual, su valor de $\Delta \mathbf{L}_{\mathbf{x d}}(\%)$ permaneció prácticamente constante hasta el fin del ensayo, 2 años. Este grupo corresponde a los CPO -6- y a los CPRS -4- (Grupo $\mathbf{a}_{\mathbf{0}}$ ). the ettringites. The latter two analyses were conducted on $20 \mathrm{~g}$ of each PC or POZC (with 33,3\% instead of $15,05 \%$ gypsum), which were likewise stored in the respective amount of water, after a very slow setting process.

\section{RESULTS, DISCUSSION AND INTERPRETATION}

The experimental values obtained for $\Delta L(\%)$ are plotted against time in the curves in Figure 1, which have been divided into two separate groups for the present discussion:

(ao) Concave curves (thick solid line in Figure 1) with widely different values for $\Delta L_{7 D}(\%)$ and $\Delta L(\%)$ at the age when the curve flattened, from which time the $\Delta L_{x d}(\%)$ value remained practically constant through the end of the test (two years). All six OPCs and the four SRPCS exhibited this behaviour (Group ao). 
(bo) Grupo de curvas convexas (de línea inicialmente discontinua y fina en la Figura 1) las cuales tienden a ser tanto más pronto horizontales cuanto mayores son los contenidos de $M K$ y $C_{3} A$ del PUZC, y viceversa. Este grupo corresponde a las 10 diferentes familias PUZC (Grupo $\mathbf{b}_{\mathbf{0}}$ ).

NOTA ACLARATORIA: El análisis, estudio, discusión e interpretación del Grupo de curvas (ao) junto con una porción de curvas del Grupo ( $\left.b_{0}\right)$, ha sido el objeto de la Parte I (1) de esta investigación, mientras que el resto de este último Grupo de curvas $\left(b_{0}\right)$ es el objeto de esta Parte II.

Como se acaba de ver, todos los resultados experimentales obtenidos, representados gráficamente, han proporcionado unas curvas que a su vez se han dividido en dos grupos (Figura 1): el Grupo ( $\left.\mathbf{a}_{\mathbf{0}}\right)$ o Grupo de curvas "convexas" y el Grupo (bo) o Grupo de curvas "cóncavas". Ambos grupos de curvas se caracterizan porque,

- el Grupo ( $\mathbf{a}_{\mathbf{o}}$ ) comprende claramente todos los CPO y los CPRS (ya vistos, analizados y estudiados en la Parte I (1) de esta investigación), y

- el Grupo (bo) comprende claramente todos sus PUZC con MK.

Asimismo, ambos grupos de curvas se obtuvieron dibujando los $\Delta \mathbf{L}(\%)$ vs. tiempo, y todos los valores de $\Delta \mathbf{L}(\%)$ fueron debidos a la expansión de ettringitas (5-11). Por otra parte, la formación de ettringita del $\mathrm{C}_{3} \mathrm{~A}$ presente en los CPO fue verificada mediante trabajos previos (4-10); y del mismo modo también se logró demostrar que las adiciones puzolánicas forman también ettringita durante su exposición a la misma disolución de sulfatos $(4,5)(7-10)$.

Por consiguiente y de acuerdo con estos trabajos previos (4-10), se puede decir con fundamento que si dos grupos de curvas son muy diferentes entre sí -el primer grupo o Grupo ( $\left.\mathbf{a}_{\mathbf{0}}\right)$ es "cóncavo", y el segundo grupo o Grupo ( $\mathbf{b}_{\mathbf{0}}$ ) es "convexo"-, la causa que las originó debe ser también muy diferente entre sí. Esto indica, una vez más, que la ettringita de la $\mathrm{Al}_{2} \mathrm{O}_{3}{ }^{\mathrm{r}-}$ del $\mathrm{MK}$ o ett-rf, debe de formarse más rápidamente que la ettringita de origen $\mathrm{C}_{3} \mathrm{~A}$ de los $\mathrm{CPO}$.

No obstante, suponiendo una vez más que la $\mathbf{V}_{\mathbf{f}}$ de la ett-rf es igual a la $\mathbf{V}_{\mathbf{f}}$ de la ett-If, sea cual fuere la familia de PUZC que se considere, sus curvas "convexas" (ver la Figura 1), deberían de haber sido también "cóncavas" y paralelas a la curva "cóncava" de su respectivo CP puro, y en cualquier caso, se habría obtenido la siguiente clasificación, (bo) Convex curves (initially dashed, fine-line curves in Figure 1), which tend to flatten very quickly with rising $M K$ and $C_{3} A$ contents in the POZC and vice-versa. This was the behaviour observed in the ten POZC families.

CLARIFICATION: The Group (ao) curves and some of the Group $\left(b_{0}\right)$ curves were analyzed in Part $I$ of this study, while the remaining Group ( $\left.b_{0}\right)$ curves are addressed in the present Part II.

Briefly, then:

- Group (ao) clearly includes all the OPCs and SRPCS (analyzed in Part I (1) of this study) and

- Group ( $b_{0}$ ) clearly includes all the MK-containing POZCS.

Both groups of curves were obtained by plotting $\Delta L(\%)$ values, a reflection of ettringite expansion (5-11), against time. Ettringite formation from the $C_{3} A$ present in OPCs was verified in earlier papers (4-10), which likewise showed that pozzolanic additions also form ettringite when exposed to the same aggressive sulphate solution $(4,5)(7-10)$.

Based on that earlier evidence (4-10), it may be correctly maintained that the significant variation in the two groups of curves (one, Group ( $a_{0}$ ) being concave and the other, Group ( $\left.b_{0}\right)$, convex), must reflect differences in the underlying processes. This provides further proof that the ettringite from the $\mathrm{Al}_{2} \mathrm{O}_{3}{ }^{r-}$ present in the $\mathrm{MK}$ (ett-rf) must form more quickly than the ettringite deriving from the $C_{3} A$ in OPCS.

Nonetheless, if the $V_{f}$ for ett-rf were equal to the $V_{f}$ for ett-If regardless of the POZC family involved, the respective convex curves (see Figure 1) should have been concave and parallel to the concave curves for their respective pure PCs. In that case, the following inequality would hold:

$$
>\Delta L(\%)>; \text { CPO-no/M ó CPRS-n } \% \text { M 100/00 8 80/20 > 70/30 > 60/40 }
$$


Sin embargo, este comportamiento no se ha obtenido, sino el contrario; debido a que las curvas de cada familia de PUZC fueron tanto más contrarias a la curva de su respectivo CP puro (o sea, "convexas"), cuanto mayor fue la cantidad de MK que se le añadió al mismo, por ejemplo, al CPO P-1. Entonces y de acuerdo con este último comportamiento, la $\mathbf{V}_{\mathbf{f}}$ de la ett-rf debe de ser también necesariamente, totalmente contraria o diferente a la $\mathbf{V}_{\mathbf{f}}$ de la ett-lf, es decir,

- o la $\mathbf{V}_{\mathbf{f}}$ de la ett-rf es mucho mayor que la $\mathbf{V}_{\mathbf{f}}$ de la ett-lf,

- o es mucho más pequeña,

lo que verifica de nuevo que la anterior suposición no es correcta.

Pero es que además, la $\mathbf{V}_{\mathbf{f}}$ de la ett-rf no puede ser más pequeña que la $\mathbf{V}_{\mathbf{f}}$ de la ett-If, porque de acuerdo con la regla de Von Weimarn y Garrido $(17,18)$, sus cristales tendrían que ser de mayor tamaño que los de la ett-If. $Y$ dichos cristales no han sido mayores de tamaño, sino que, una vez más, han sido exactamente lo contrario, es decir, han sido más pequeños ( $\approx 10$ veces más pequeños) (Figuras $2(a)(b)(c), 3(a)(b)(c), 4$ y 5$)$. Von Weimarn y Garrido

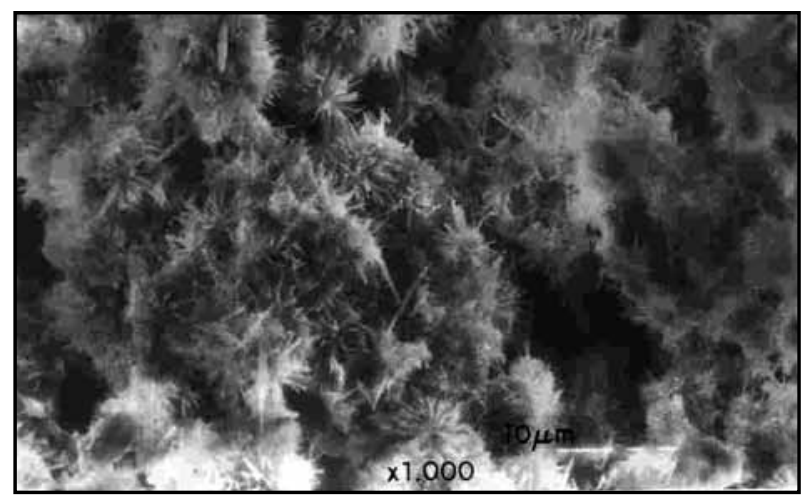

Figura 3(a). Ettringitas de "lenta" formación. Figure 3(a). Slow forming ettringite(ett-lf).
But this was not the behaviour observed. Indeed, in each POZC family, the higher the proportion of $M K$ added to the respective pure $P C$, the more convex was the curve, such as in OPC P-1, for instance. Further to this behaviour, the $V_{f}$ for ett-rf must necessarily be completely contrary to the $V_{f}$ for ett-If; in other words:

- the $V_{f}$ for ett-rf is either much higher than the $V_{f}$ for ett-If

- or it is much lower.

In either case, the initial hypothesis is obviously mistaken.

To continue with this line of reasoning, if the $V_{f}$ for ett-rf were lower than the $V_{f}$ for ett-If, pursuant to the Von Weimarn and Garrido rule $(17,18)$, its crystals would have to be larger than the ett-If crystals. But this was not the case: i.e., the crystals were (around 10 times) smaller in ett-rf than in ett-If (Figures $2(a)(b)(c)$, $3(a)(b)(c), 4$ and 5). Von Weimarn and Garrido showed that a salt's precipitation rate is directly proportional to

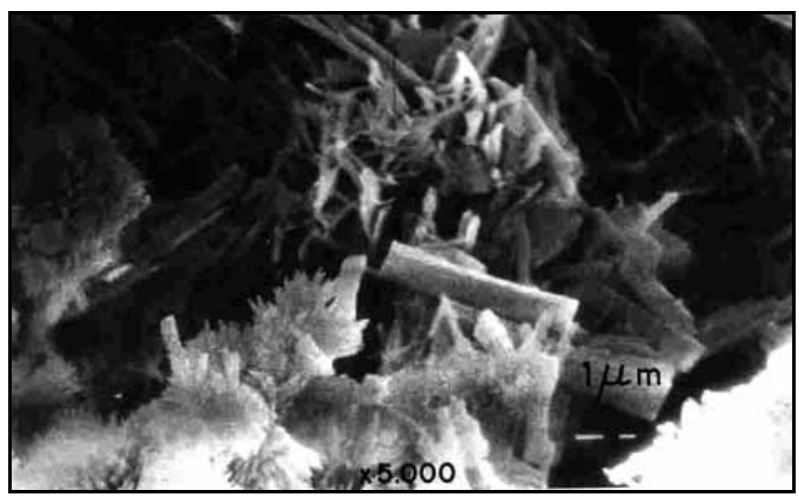

Figura 3(b). Ettringitas de "lenta" formación. Figure 3(b). Slow forming ettringites (ett-If).

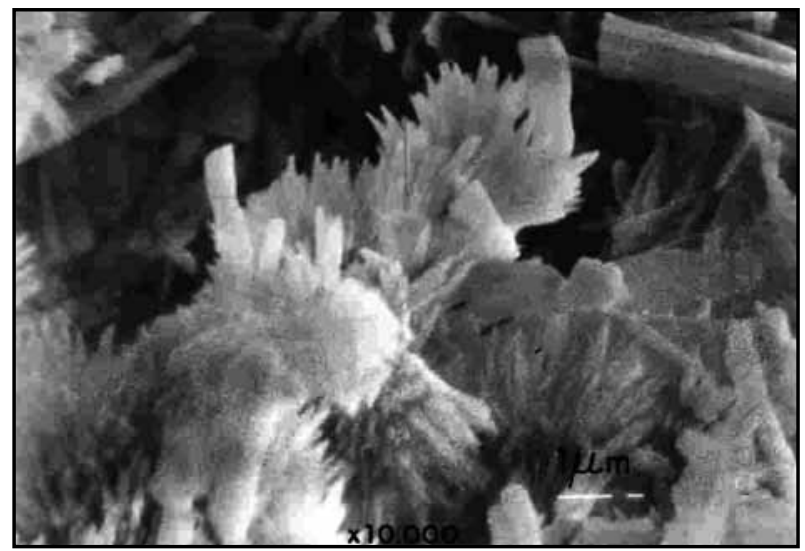

Figura 3(c). Ettringitas de "lenta" formación. Figure 3(c). Slow forming ettringites (ett-lf). 
han demostrado, acerca de la formación de cristales por precipitación, que la velocidad de precipitación de una sal es directamente proporcional al grado de sobresaturación e inversamente proporcional a su solubilidad -que en el caso de le ettringita en disolución acuosa de $\mathrm{Ca}(\mathrm{OH})_{2}$ oscila entre 0,255 y $0,024 \mathrm{~g}$ ett/l para disoluciones acuosas de $\mathrm{Ca}(\mathrm{OH})_{2}$ comprendidas entre 0,056 y $1,08 \mathrm{~g} \mathrm{CaO} / \mathrm{l}$, siendo la solubilidad del $\mathrm{Ca}(\mathrm{OH})_{2}$ en agua, $1,20 \mathrm{~g} \mathrm{CaO} / \mathrm{l}$ a $18^{\circ} \mathrm{C}-$. $\mathrm{O}$ dicho de otro modo: la velocidad inicial de precipitación de una sal es proporcional a la sobresaturación relativa $[(\mathbf{Q}-\mathbf{S}) / \mathbf{S}]$, donde,

- $\mathbf{Q}$, es la concentración total de la sustancia que precipita,

- S, es la solubilidad, es decir, la concentración de la disolución en equilibrio con el precipitado, y

- Q-S, es la sobresaturación cuando comienza la precipitación.

Esa expresión sólo se cumple con suficiente exactitud, cuando $\mathbf{Q}$ es comparativamente mucho mayor que $\mathbf{S}$, en cuyo caso, el tamaño del cristal de un precipitado disminuye al aumentar la concentración de las sustancias reaccionantes (caso de le formación de la ett-rf o de origen $\mathrm{Al}_{2} \mathrm{O}_{3}{ }^{\mathrm{r}-}$ de una puzolana, en este caso).

Por lo tanto y según Von Weimarn y Garrido, si los reactivos se mezclan de manera que se produzca un elevado grado de sobresaturación -caso de la $\mathrm{Al}_{2} \mathrm{O}_{3}{ }^{\mathrm{r}}$ - de una puzolana-, tiene lugar una rápida precipitación. De este modo se obtiene un precipitado gelatinoso que es causa y origen de cristales de pequeño tamaño -caso de la ett-rf- formados por tanto, rápidamente. Por el contrario, la adición lenta del agente precipitante a una disolución diluida, origina únicamente una ligera sobresaturación; con lo que aparece lentamente un precipitado formado por macro-cristales -caso de la ett-If- formados, por tanto, lentamente.

Además, la regla de Von Weimarn y Garrido apostilla que cuanto más insoluble es una sal -y la ettringita lo es-, tanto más difícil es conseguir una precipitación lenta y unos cristales grandes y bien definidos, como así se ha obtenido en este trabajo. Véanse las Figuras 2(a)(b)(c), 3(a)(b)(c), 4 y 5.

En definitiva, los cristales obtenidos con débil sobresaturación presentan la misma forma que los que se obtienen en fase vapor (o sea, sin disolvente), y las velocidades de crecimiento más pequeñas corresponden a caras con un campo eléctrico débil. En cambio, cuando el crecimiento se efectúa con fuerte sobresaturación, se produce una inversión en el orden de las velocidades de crecimiento, y son las caras con campo fuerte, las que tienen una velocidad de crecimiento mínima.

Esta inversión puede explicarse teniendo en cuenta que cuando la disolución está fuertemente sobresaturada, the degree of supersaturation and indirectly proportional to its solubility, which in the case of ettringite in an aqueous $\mathrm{Ca}(\mathrm{OH})_{2}$ solution $(0,056$ to $1,08 \mathrm{~g} \mathrm{CaO} / \mathrm{l}$ ) ranges from 0,255 to $0,024 \mathrm{~g}$ ett/l. $\mathrm{Ca}(\mathrm{OH})_{2}$ solubility in water at $18^{\circ} \mathrm{C}$ is $1,20 \mathrm{~g} \mathrm{CaO} / \mathrm{l}$. To put it another way: the initial precipitation rate of a salt is proportional to relative supersaturation $[(Q-S) / S]$ where:

- $Q$ is the total concentration of the precipitate

- $S$ is solubility, i.e., the equilibrium concentration of the solution, and

- Q-S is supersaturation when precipitation begins.

This expression is only sufficiently accurate when $Q$ is much larger than $S$, in which case the size of precipitating crystals declines with rising reagent concentration (as in the formation of ett-rf from the $\mathrm{Al}_{2} \mathrm{O}_{3}{ }^{r-}$ present in pozzolans).

Therefore, according to Von Weimarn and Garrido, if the reagents are mixed in a way that leads to high supersaturation - such as $\mathrm{Al}_{2} \mathrm{O}_{3}{ }^{r}$ - in pozzolans - precipitation takes place swiftly, leading to a gel-like precipitate which is the cause and origin of small, rapidly forming crystals, such as in ett-rf. On the contrary, the gradual addition of a precipitating agent to a dilute solution leads to only slight supersaturation, which in turn gives rise to the precipitation of slow-forming macro-crystals, such as in ett-If.

Moreover, one of the implications of the Von Weimarn and Garrido rule is that the more insoluble a salt (and ettringite is indeed insoluble), the more difficult it is to obtain slow precipitation and large and well defined crystals, such as observed in this study. See Figures $2(a)(b)(c), 3(a)(b)(c), 4$ y 5 .

Crystals obtained with slight supersaturation, in turn, have the same shape as those obtained in a gas phase (i.e., with no solvent) and the lowest growth rates are exhibited by the sides with a weak electric charge. When growth takes place in a highly supersaturated medium, however, the order of growth rates is inverted, with lower growth observed for the sides with a strong field.

This inversion can be explained by the fact that when the solution is strongly supersaturated, ions in solution 


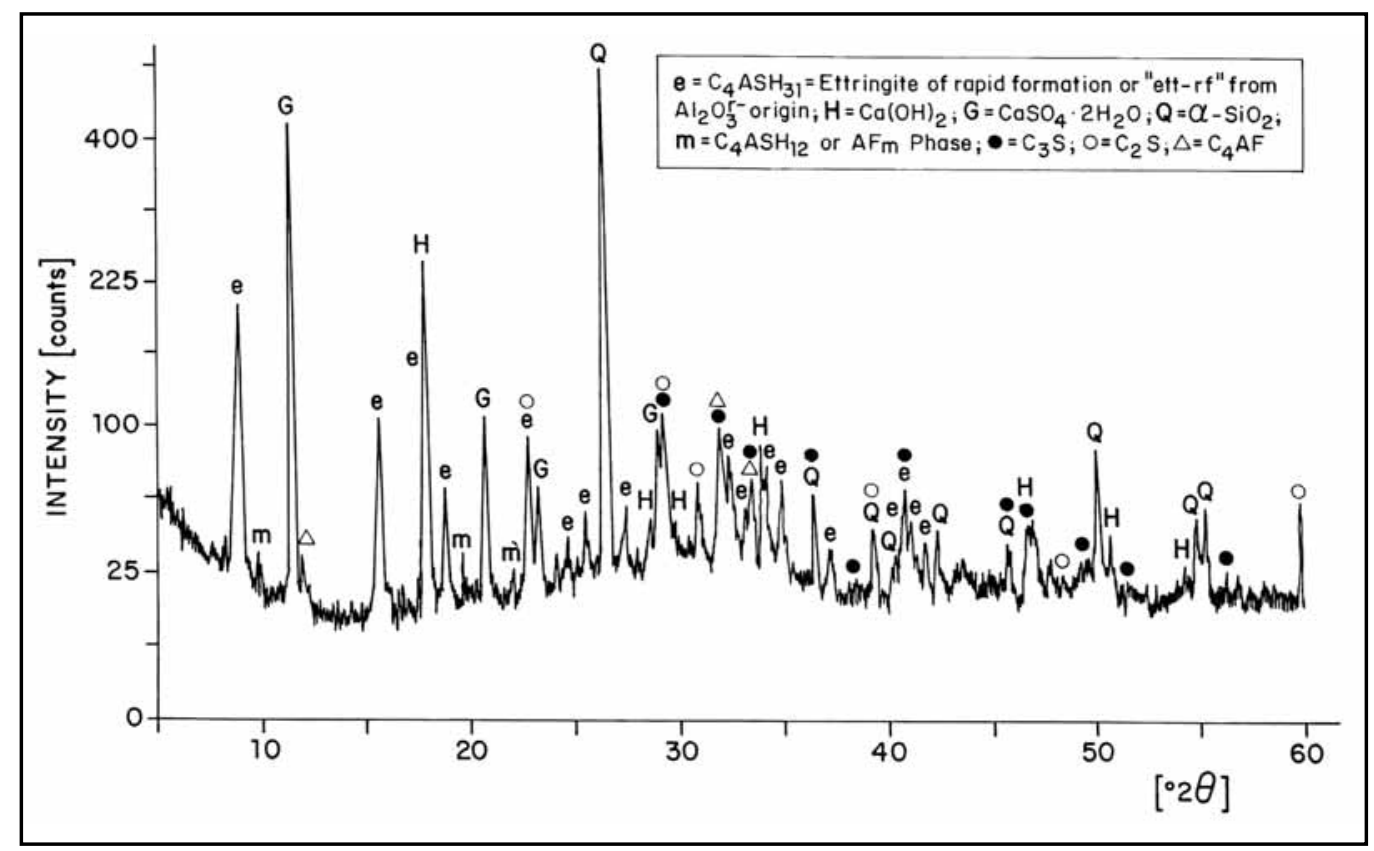

Figura 4. Ettringita de "rápida" formación. Figure 4. Rapid forming ettringite (ett-rf).

los iones en disolución y los dipolos adoptan una configuración diferente que cuando la disolución es la correspondiente a la saturación. En el contacto cristal-disolución, se producen fenómenos diferentes de solvatación. Como con fuerte sobresaturación la disolución es más pobre en disolvente, debe resultar una desolvatación. Y ésta es más fácil de obtener en los planos reticulares con campo débil. Lo que hace que estos planos aumenten su velocidad de crecimiento que podrá sobrepasar incluso la velocidad del plano con campo fuerte.

El grado de sobresaturación necesario para provocar el cambio de facies será tanto más elevado, cuanto más fuerte sea la unión cristal-disolvente, y cuanto menor sea la solubilidad de la sal (y la ettringita lo es). Existe pues una interacción muy marcada entre el disolvente y el cristal, y las caras $\mathbf{F}$, que son las que aparecen en estado de equilibrio, pueden ser sustituidas por caras $\mathbf{S}$ o K. A este respecto, se debe recalcar de nuevo que las caras $\mathbf{F}$ son las únicas que crecen de un modo reproducible con una superficie plana; a escala atómica, pueden tener escalones de modo variado (véase la Figura 6), pero éstos unen grandes superficies perfectamente planas, caso de la ett-If, véase de nuevo la Figura 6. Las caras $\mathbf{S}$ y $\mathbf{K}$, por el contrario, no crecen de un modo reproducible; pueden no ser planas ni estar formadas por capas, caso de la ett-rf, véanse las Figuras 2(b) y (c).

Lógicamente y si se tiene en cuenta la concluyente explicación dada, la determinación exacta de las dimensiones de ambos tipos de ettringita carece de sentido, y además, apenas tiene interés técnico, lo que ha justificado no haberla considerado por nuestra parte entre los objetivos de este trabajo. and dipoles adopt a configuration other than the saturation configuration, the solvation phenomena taking place at the crystal-solution interface must differ. In highly supersaturated solutions with a low solvent content, this must involve de-solvation, which occurs more readily on reticular planes with a weak field. The resulting increase in the growth rate for these planes may even outpace the rate prevailing on strong field sides.

The stronger the crystal-solvent bond and the lower the solubility of the salt, the higher is the degree of supersaturation needed to occasion this change in facies. The solvent interacts intensely, then, with the crystal and the $\boldsymbol{F}$ sides, the sides that appear in equilibrium, may be replaced by $\boldsymbol{S}$ or $\boldsymbol{K}$ sides. Be it said in this regard that the $F$ sides are the only ones that grow reproducibly, with flat surfaces; while on the atomic scale they may be stair-stepped, the prevailing shape is a large, perfectly flat surface, such as in ettIf (see Figure 6). Sides $\boldsymbol{S}$ and $\boldsymbol{K}$, on the contrary, do not grow reproducibly, and are neither flat nor layered. This is the case of ett-rf (see Figures 2(b) and (c)).

Logically, in light of the above conclusive explanation, the determination of the exact dimensions of the two types of ettringite would be senseless and of scant technical interest, for which reason it was not included among the objectives of the present study. 
Por último y a la vista de los valores de $\Delta \mathbf{L}_{\mathbf{x d}}(\%)$ obtenidos de todos los PUZC estudiados, es necesario destacar también los siguientes comportamientos: El $\Delta \mathbf{L} \mathbf{7 d}=0,094 \%$ del CPO P-1 significa o equivale solamente al $9,77 \%$ de su correspondiente $\Delta \mathbf{L}_{\mathbf{1 2 0 d}}(\%)=0,962 \%$; pero si el que se considera como máximo $\Delta \mathbf{L}(\%)$ es el de 730 días = 0,974\%, su $\Delta \mathbf{L}_{\mathbf{7 d}}(\%)$ sería equivalente al 9,65\% solamente. $Y$ generalizando, cualquier $\Delta \mathbf{L}(\%)$ máximo que se considere, producido por el CPO P-1, su correspondiente valor de $\Delta \mathbf{L}_{\mathbf{7 d}}(\%)$ es siempre una cantidad muy pequeña, lo que a su vez debe significar que, la $\mathbf{V}_{\mathbf{f}}$ de la ettringita que originó ambos valores, el de $\Delta \mathbf{L}_{\mathbf{7 d}}(\%)$ y el de $\Delta \mathbf{L}_{\mathbf{x d}}(\%)$ máximo, debe de ser muy pequeña también. $Y$ lo mismo se puede decir prácticamente, para el resto de CPO. En cambio,

- el valor de $\Delta \mathbf{L}_{\mathbf{7 d}}(\%)$ del PUZC P-4/M 80/20 es = $0,171 \%$, lo que significa o equivale al $98,84 \%$ de $0,173 \%$ (= su máximo valor de $\Delta \mathbf{L}(\%)$ ),

- el valor del $\Delta \mathbf{L}_{\mathbf{7 d}}(\%)$ del PUZC P-4/M 70/30 es $=$ $0,183 \%$, lo que equivale al $97,34 \%$ de $0,188 \%$ (= su máximo valor de $\Delta \mathbf{L}(\%))$, y

- el valor del $\Delta \mathbf{L}_{\mathbf{7 d}}(\%)$ del PUZC P-4/M 60/40 es = $0,250 \%$, lo que equivale al $92,93 \%$ de $0,250 \%$ (= su máximo valor de $\Delta \mathbf{L}(\%)$ ).

Esto es, cualquier PUZC y su máximo valor de $\Delta \mathbf{L}_{\mathbf{x d}}(\%)$ que se considere, su correspondiente valor de $\Delta \mathbf{L} 7 \mathbf{d}(\%)$ originado previamente es un valor muy elevado, el cual a su vez debe significar que la $\mathbf{V}_{\mathbf{f}}$ de la ettringita de este otro cemento de mezcla que originó ambos valores de $\Delta \mathbf{L}(\%)$ a 7 días y a " $\mathbf{x "}$ días, debe ser, por esta otra razón, muy elevada también.
Lastly, the most significant findings relating to the $\Delta L_{x d}(\%)$ values obtained for all the POZCs studied are discussed below. The $\Delta L_{7 d}$ for OPC-P1 $(0,094 \%)$ accounted for only $9,77 \%$ of its respective $\Delta L_{120 d} \%(0,962 \%)$ and just $9,65 \%$ of its $\Delta L_{730 d}(\%)(0,974 \%)$. More generally, regardless of the maximum $\Delta L(\%)$ assumed for OPC $P-1$, the $\Delta L_{7 d}(\%)$ value was always a very small amount. This, in turn, means that the $V_{f}$ of the ettringite generating the two values, $\Delta L_{7 d}(\%)$ and maximum $\Delta L_{x d}(\%)$, must be very slow. The same reasoning may be applied to all the other OPCs. On the contrary:

- the $\Delta L_{7 d}(\%)$ value for POZC P-4/M 80/20 was 0,171 $\%$, or $98,84 \%$ of the maximum $\Delta L(\%)$ value of $0,173 \%$.

- he $\Delta L_{7 d}(\%)$ value for POZC P-4/M 70/30 was 0,183 $\%$, which is equivalent to $97,34 \%$ of its maximum $\Delta L(\%)$ value, $0,188 \%$.

- the $\Delta L_{7 d}(\%)$ value for POZC P-4/M 60/40 was 0,250 $\%$, i.e., $92,93 \%$ of the maximum $\Delta L(\%)$, which came to $0,250 \%$.

Regardless, then, of the maximum $\Delta L(\%)$ value assumed for any $P O Z C$, its respective $\Delta L_{7 d}(\%)$ value was very high, inferring that the $V_{f}$ of the ettringite in such blended cements must likewise be very high.

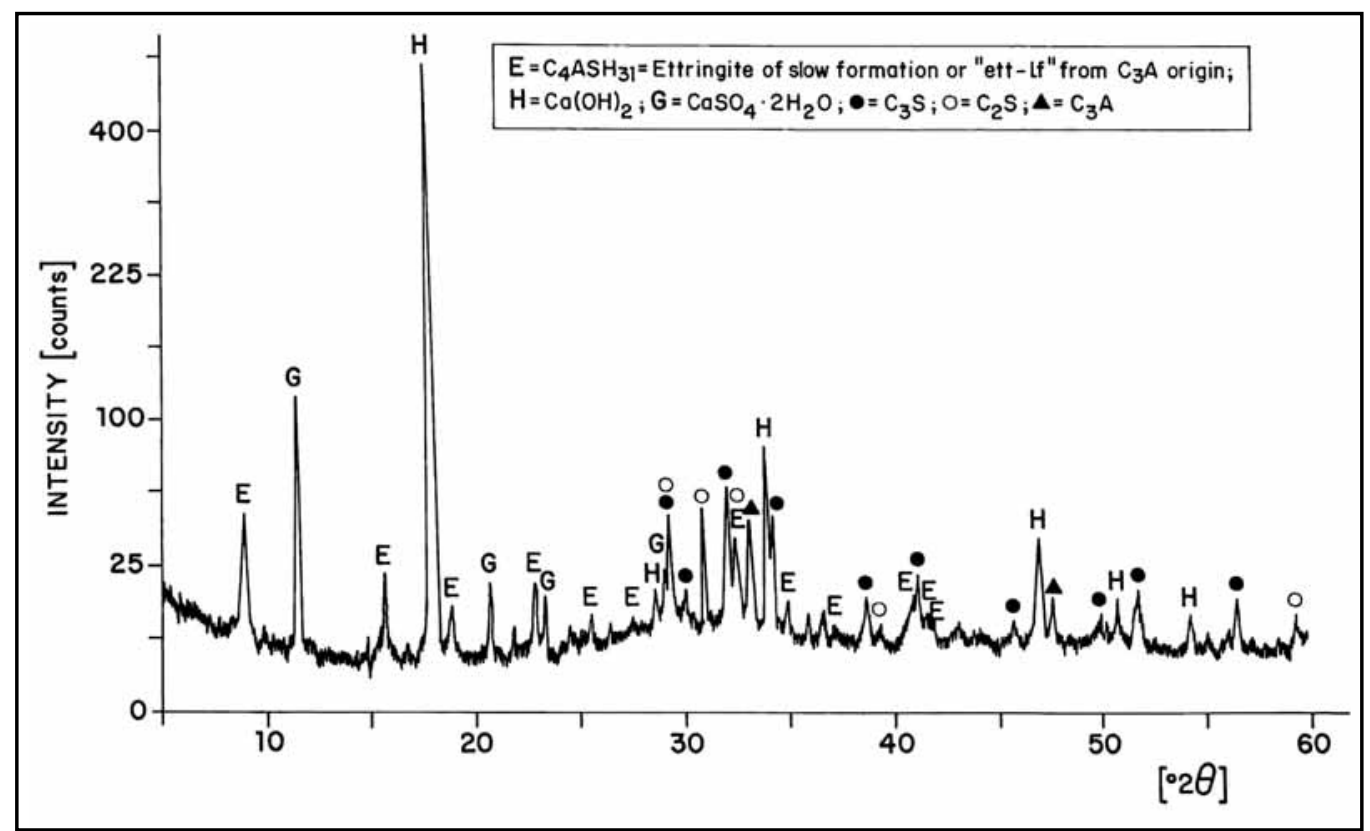

Figura 5. Ettringita de "lenta" formación.

Figure 5. Slow forming ettringite (ett-lf). 

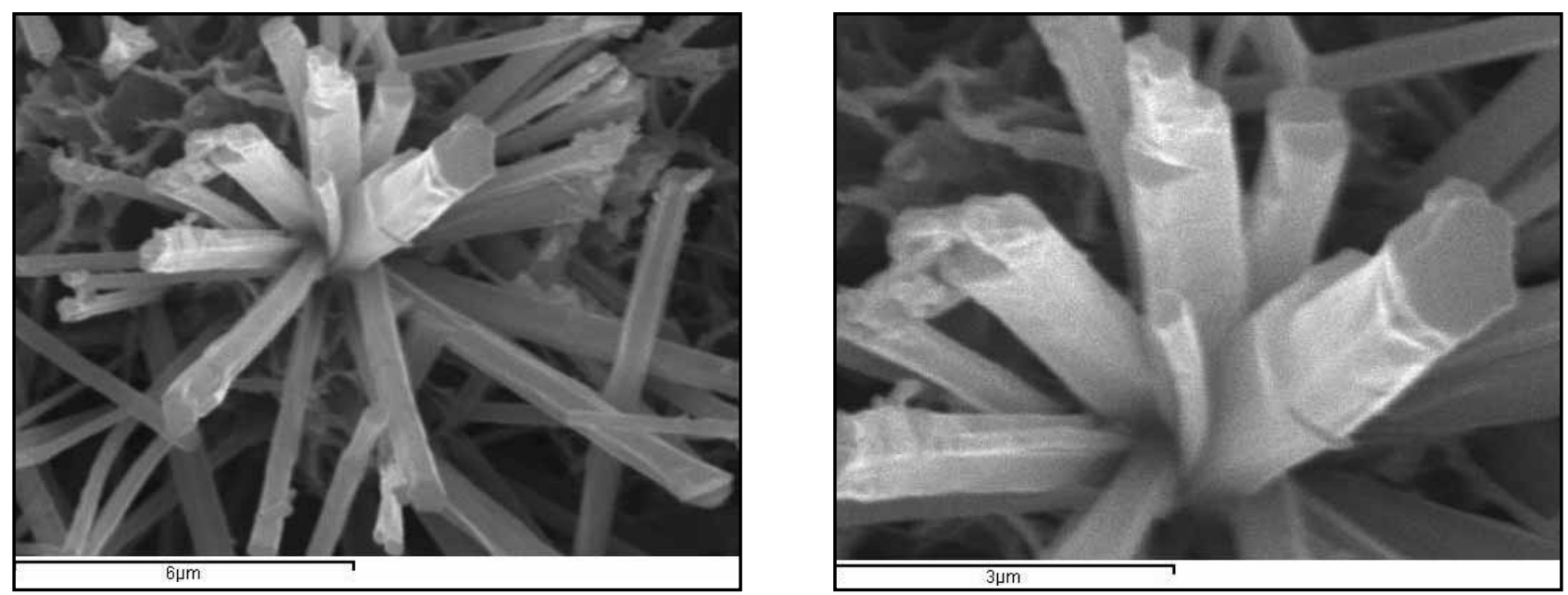

Figura 6. Ettringita de "lenta" formación.

Figure 6. Slow forming ettringite (ett-rf).

O de otra manera, mientras que la longitud de las probetas del CPO P-1 aumentó hasta la edad de 2 años, o al menos, hasta la edad de 60 ó 90 días sólo, la de las probetas $60 / 40$ y $70 / 30$, principalmente, de la familia PY4/M, por ejemplo, habían logrado alcanzar prácticamente casi todo su máximo $\Delta \mathbf{L}(\%)$, a la edad de 7 ó 14 días a lo sumo. $Y$ del mismo modo, casi todas las demás familias de PUZC a la edad de 7 días.

Por lo tanto y en definitiva, durante las primeras edades, todos los PUZC originaron sus valores de $\Delta \mathbf{L}(\%)$ elevados, lo que no lograron originar sus correspondientes CP puros, los cuales los originaron siempre mucho más tarde. Además, cuanto mayor fue la cantidad de MK añadida al $\mathrm{CP}$, más elevado fue el valor de $\Delta \mathbf{L}(\%)$ que originó, y más pronto lo originó todavía, y viceversa.
In other words, while the length of the OPC P-1 specimens grew throughout the two-year period, or at least for the first 60 or 90 days, the 60/40 and 70/30 PY-4/M family specimens attained nearly their maximum $\Delta L(\%)$ at the age of seven or fourteen days. This was likewise the case of the seven-day specimens in practically all the other POZC families.

In short, all the POZCs originated high $\Delta L(\%)$ values at early ages, unlike the respective pure OPCS, in which such values rose much more gradually. Furthermore, the higher the amount of $M K$ added to the $P C$, the higher was the $\Delta L(\%)$ value and the earlier its generation.

Tabla 3 / Table 3

Resistencias mecánicas de los CPO, P-1 y P-2, del CPRS PY- 6 y de sus PUZC con MK.

Mechanical strength found for OPCS P-1 and P-2, SRPC PY-6, and their M-pozzolan POZCs.

\begin{tabular}{|c|c|c|c|c|c|c|c|c|}
\hline \multirow{4}{*}{$\begin{array}{c}\text { Cementos I } \\
\text { Cement }\end{array}$} & \multicolumn{8}{|c|}{$\begin{array}{c}\text { Resistencias mecánicas RM / Mechanical strength, MS } \\
\text { tipos de mortero / (cement mortar types: }-7.0 \% \mathrm{SO}_{3} \Rightarrow \mathrm{EN} 196-1 ;+7.0 \% \mathrm{SO}_{3} \rightarrow \mathrm{ASTM} \mathrm{C452}^{-68)}\end{array}$} \\
\hline & \multicolumn{4}{|c|}{ Flexotracción / Flexural strength, FS (MPa) } & \multicolumn{4}{|c|}{ Compresión / Compressive strength, CS (MPa) } \\
\hline & \multicolumn{2}{|c|}{28 días / 28 days } & \multicolumn{2}{|c|}{90 días / 90 days } & \multicolumn{2}{|c|}{28 días / 28 days } & \multicolumn{2}{|c|}{90 días / 90 days } \\
\hline & $-7.0 \% \mathrm{SO}_{3}$ & $+7.0 \% \mathrm{SO}_{3}$ & $-7.0 \% \mathrm{SO}_{3}$ & $+7.0 \% \mathrm{SO}_{3}$ & $-7.0 \% \mathrm{SO}_{3}$ & $+7.0 \% \mathrm{SO}_{3}$ & $-7.0 \% \mathrm{SO}_{3}$ & $+7.0 \% \mathrm{SO}_{3}$ \\
\hline $\mathrm{P}-1$ 100/00 & 7.0 & 4.4 & 7.3 & 8.9 & 47.7 & 27.7 & 50.3 & 53.0 \\
\hline $\mathrm{P}-1 / \mathrm{M} 80 / 20$ & 8.2 & 9.7 & 8.4 & 10.3 & 54.9 & 40.1 & 55.9 & 39.3 \\
\hline $\mathrm{P}-1 / \mathrm{M} 70 / 30$ & 8.7 & 8.9 & 8.9 & 9.8 & 53.3 & 32.6 & 54.3 & 48.6 \\
\hline $\mathrm{P}-1 / \mathrm{M} 60 / 40$ & 8.6 & 8.5 & 8.8 & 8.9 & 48.3 & 43.6 & 49.2 & 45.7 \\
\hline P-2 100/00 & 4.0 & 4.4 & 4.2 & 5.2 & 27.3 & 18.3 & 32.4 & 29.7 \\
\hline $\mathrm{P}-2 / \mathrm{M} 80 / 20$ & 8.2 & 9.8 & 8.4 & 10.5 & 60.8 & 38.0 & 61.9 & 43.6 \\
\hline $\mathrm{P}-2 / \mathrm{M} 70 / 30$ & 9.7 & 9.5 & 9.9 & 9.7 & 49.7 & 38.8 & 50.6 & 45.4 \\
\hline $\mathrm{P}-2 / \mathrm{M} 60 / 40$ & 7.7 & 8.6 & 7.9 & 8.9 & 45.7 & 41.1 & 46.5 & 43.3 \\
\hline PY-6 100/00 & 7.8 & 6.1 & 7.3 & 7.4 & 54.3 & 30.9 & 63.0 & 32.7 \\
\hline PY-6/M 80/20 & 8.8 & 6.5 & 9.8 & 9.3 & 59.8 & 47.3 & 71.6 & 54.5 \\
\hline PY-6/M 70/30 & 9.5 & 9.2 & 10.4 & 11.0 & 57.2 & 32.1 & 68.4 & 47.8 \\
\hline PY-6/M 60/40 & 7.3 & 10.1 & 8.1 & 10.7 & 54.3 & 39.3 & 54.6 & 46.4 \\
\hline
\end{tabular}


Por otra parte, esta última observación vendría a indicar por tanto, que esta clase de PUZC con MK (que debe poseer un elevado contenido de $\mathrm{Al}_{2} \mathrm{O}_{3} \mathrm{r}^{-}(\%)$ ), serán dañados y destruidos por ataque sulfático, más pronto que sus respectivos $\mathrm{CP}$ puros, como así se ha logrado demostrar en el laboratorio, cuando estos PUZC se ensayaron conforme el método RT: $\Delta \mathrm{L}$ (Tabla 5 ), y en alguna experiencia real española (19). Por tanto, la destrucción más rápida causada por ataque del yeso ha podido ser acelerada por la presencia del $\mathrm{MK}$, haciendo que el ciclo de vida útil previsto de su PUZC, disminuya, incluso, muy seriamente. Este efecto deletéreo derivado del ataque del yeso, se produjo tan rápido y en tal medida, que pudo ser considerado una vez más un ATAQUE RÁPIDO DEL YESO (7-9), lo que quizás justificaría también, algunos de los resultados experimentales obtenidos por K. Mather, Mehta y Tikalsky y Carrasquillo (20-22).

No obstante lo anterior, cuando la cantidad de sulfatos adicionada a estos materiales cementíceos utilizados (MK y $\mathrm{CP}$ ) ha sido tal que su contenido final ha sido del $7,0 \%$ $\mathrm{SO}_{3}$, equivalente a $15,05 \%$ de yeso, y ensayados conforme el método ASTM C 452-68, la misma no se ha comportado como agresivo sino como "regulador de fraguado". Ya que los aumentos de resistencias mecánicas con el transcurso del ensayo (Tabla 3) y los tiempos de fraguado (Tabla 4) de estas mezclas fueron similares a los observados para cualquier CP. Sin embargo, cuando el
Moreover, this final observation would infer that $M K$ containing POZCs (which must have a high $\mathrm{Al}_{2} \mathrm{O}_{3}{ }^{r-}(\%)$ content) would be destroyed by sulphate attack more readily than the respective pure $P C$. Laboratory tests of the POZC specimens using the RT: $L L$ method (Table 5) and actual incidents reported in Spain (19) corroborate that inference. Consequently, gypsummediated destruction may have been accelerated by the presence of $M K$, thereby reducing, perhaps substantially, the service life of the POZC. This harmful effect was generated so swiftly and extensively that it could be regarded to constitute RAPID GYPSUM ATTACK (7-9) and might also explain some of the experimental results obtained by $K$. Mather, Mehta and Tikalsky, and Carrasquillo (20-22).

That notwithstanding, when the amount of sulphates added to these cementitious materials ( $M K$ and $P C$ ) was equivalent to $7,0 \% \mathrm{SO}_{3}$ (or 15,05\% gypsum), according to the ASTM C 452-68 test results, it behaved not like an aggressive agent, but as a "setting regulator". Indeed, the increases in mechanical strength over time (Table 3) and the setting times (Table 4) recorded for these blends were similar to the findings for any $P C$. When the gypsum was trebled, however (to $21,0 \%$ in the RT: $\Delta L$ test), it behaved aggressively (Table 5) and

Tabla 4 / Table 4

Consistencias normales, tiempos de fraguado y estabilidades de volumen de varios CP y sus PUZC con MK. Normal consistency, setting times and volume stability values for several PCs and their MK-bearing POZCs.

\begin{tabular}{|c|c|c|c|c|c|c|c|c|c|c|c|c|c|c|}
\hline & \multirow{4}{*}{\multicolumn{2}{|c|}{$\begin{array}{c}\text { Cementos / } \\
\text { Cement }\end{array}$}} & \multirow{4}{*}{ 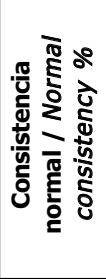 } & \multirow{3}{*}{\multicolumn{3}{|c|}{$\begin{array}{c}\text { Tiempos de fraguado } \\
\text { (Aguja de Vicat) / Setting } \\
\text { times (Vicat Needles) } \\
\text { (h., min.) }\end{array}$}} & \multicolumn{8}{|c|}{ Agujas de le chatelier / Le chatelier needles (mm) } \\
\hline & & & & & & & \multicolumn{8}{|c|}{ Agua (días) / Water (days) } \\
\hline & & & & & & & \multirow{2}{*}{$\frac{\text { A / At }}{100^{\circ} \mathrm{C}}$} & \multicolumn{7}{|c|}{ Fría / Cold $\left(\mathrm{a} /\right.$ at $\left.21+2^{\circ} \mathrm{C}\right)$} \\
\hline & & & & $\begin{array}{r}\text { Inicial / } \\
\text { Initial }\end{array}$ & $\begin{array}{c}\text { Final / } \\
\text { Final }\end{array}$ & $\begin{array}{c}\text { Tiempo de F. / } \\
\text { Setting Time }\end{array}$ & & 7 & 14 & 21 & 28 & 60 & 90 & 120 \\
\hline \multirow{4}{*}{ 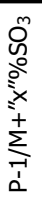 } & m̊ & $100 / 00$ & 26,0 & $2 \mathrm{~h} .00 \mathrm{~m}$ & $2 \mathrm{~h} .39 \mathrm{~m}$ & Oh.39m & 0,7 & 1,7 & 1,7 & 1,7 & 1,7 & 1,7 & 1,7 & 1,7 \\
\hline & \multirow{3}{*}{$\begin{array}{l}\stackrel{0}{0} \\
0 \\
+\end{array}$} & $80 / 20$ & 29,6 & 3h.15m & $4 \mathrm{~h} .10 \mathrm{~m}$ & Oh.55m & 0,5 & 3,33 & 5,65 & 7,20 & 9,35 & 12,00 & 12,15 & 12,15 \\
\hline & & $70 / 30$ & 30,8 & 3h.05m & 4h. $10 \mathrm{~m}$ & $1 \mathrm{~h} .05 \mathrm{~m}$ & 0,5 & 5,15 & 6,00 & 6,33 & 6,65 & 6,71 & 6,75 & 7,75 \\
\hline & & $60 / 40$ & 32,8 & $3 \mathrm{~h} .15 \mathrm{~m}$ & 4h. $10 \mathrm{~m}$ & 0h. $55 \mathrm{~m}$ & 0,5 & 5,75 & 5,75 & 5,75 & 5,75 & 5,75 & 5,75 & 5,75 \\
\hline \multirow{4}{*}{ 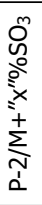 } & $\begin{array}{l}\stackrel{9}{\ddagger} \circ 0 \\
+ \\
+\end{array}$ & $100 / 00$ & 24,0 & $2 \mathrm{~h} .10 \mathrm{~m}$ & $3 \mathrm{~h} .09 \mathrm{~m}$ & Oh.59m & 0,8 & 2,6 & 2,6 & 2,6 & 2,6 & 2,6 & 2,6 & 2,6 \\
\hline & \multirow{3}{*}{$\begin{array}{l}\stackrel{0}{0} \\
\stackrel{\circ}{+} \\
+\end{array}$} & $80 / 20$ & 28,7 & 4h. $40 \mathrm{~m}$ & 7h. $30 \mathrm{~m}$ & $2 \mathrm{~h} .50 \mathrm{~m}$ & 0,5 & 5,83 & 8,16 & 10,00 & 11,50 & 15,33 & 16,33 & 16,33 \\
\hline & & $70 / 30$ & 29,9 & $5 \mathrm{~h} .35 \mathrm{~m}$ & 7h. $55 \mathrm{~m}$ & $2 \mathrm{~h} .20 \mathrm{~m}$ & 0,5 & 6,00 & 7,50 & 8,00 & 8,16 & 8,17 & 8,00 & 8,00 \\
\hline & & $60 / 40$ & 32,2 & 4h. $35 \mathrm{~m}$ & $7 \mathrm{~h} .15 \mathrm{~m}$ & $2 \mathrm{~h} .40 \mathrm{~m}$ & 0,5 & 7,33 & 7,33 & 7,33 & 7,33 & 7,33 & 7,33 & 7,33 \\
\hline \multirow{4}{*}{ 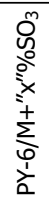 } & 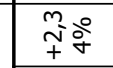 & $100 / 00$ & 21,2 & Oh.05m & Oh. $25 \mathrm{~m}$ & Oh. $20 \mathrm{~m}$ & 1,0 & 0,3 & 0,3 & 0,3 & 0,3 & 0,3 & 0,3 & 0,3 \\
\hline & \multirow{3}{*}{$\begin{array}{l}\stackrel{0}{\circ} \\
\stackrel{0}{+} \\
+\end{array}$} & $80 / 20$ & 27,2 & $6 \mathrm{~h} .15 \mathrm{~m}$ & $8 \mathrm{~h} .10 \mathrm{~m}$ & 1h. $55 \mathrm{~m}$ & 0,5 & 2,00 & 3,50 & 3,55 & 3,60 & 3,90 & 4,00 & 4,50 \\
\hline & & $70 / 30$ & 28,2 & $5 \mathrm{~h} .45 \mathrm{~m}$ & $6 \mathrm{~h} .55 \mathrm{~m}$ & $1 \mathrm{~h} .10 \mathrm{~m}$ & 0,0 & 3,20 & 3,70 & 3,80 & 4,00 & 4,60 & 4,60 & 4,70 \\
\hline & & $60 / 40$ & 31,6 & $5 \mathrm{~h} .50 \mathrm{~m}$ & 7h. $35 \mathrm{~m}$ & $1 \mathrm{~h} .45 \mathrm{~m}$ & 0,5 & 5,00 & 5,00 & 5,00 & 5,00 & 5,00 & 5,00 & 5,00 \\
\hline
\end{tabular}

NOTA: El resto de los cementos (CPO, CPRS y sus PUZC) tuvieron valores del mismo orden de magnitud para cada parámetro.

NOTE: All the other cements studied (OPC, SRPC and their POZC) reached showed values of a similar order of magnitude for the above parameters. 
Tabla 5 / Table 5

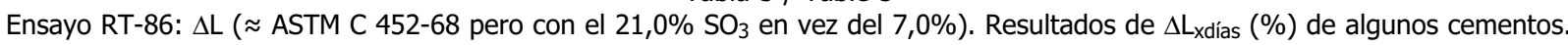
RT-86: $\Delta$ L test ( ASTM C $452-68$ test using $21.0 \%$ instead of $7.0 \%$ ) $\mathrm{SO}_{3} . \Delta \mathrm{L}_{\mathrm{xd}}$ ías $(\%$ ) values for selected cements.

\begin{tabular}{|c|c|c|c|c|c|c|c|c|c|}
\hline \multicolumn{10}{|c|}{$\begin{array}{l}\Delta \mathrm{L}_{\mathrm{xdias}}(\%) \text { de algunos CPO y CPRS y sus PUZC con MK } \mathrm{MK}^{3 *} / \\
\Delta L_{\mathrm{xdays}}(\%) \text { of some OPC and SRPC and their POZC with } M K\end{array}$} \\
\hline \multirow{2}{*}{$\begin{array}{l}\text { Edad (días)/ } \\
\text { Age (days) }\end{array}$} & \multicolumn{2}{|c|}{ CPO / OPC } & \multicolumn{3}{|c|}{ CPRS / SRPC } & \multicolumn{4}{|c|}{ PUZC / POZC } \\
\hline & P-1 & P-2 & PY-1 & PY-4 & PY-6 & $\begin{array}{l}\text { P-1/M } \\
60 / 40\end{array}$ & $\begin{array}{l}\text { PY-1/M } \\
80 / 20\end{array}$ & $\begin{array}{l}\text { PY-4/M } \\
80 / 20\end{array}$ & $\begin{array}{l}\text { PY-6/M } \\
80 / 20\end{array}$ \\
\hline 7 & 0.043 & 0.044 & 0.028 & 0.009 & 0.005 & 0.575 & 0.104 & 0.055 & 0.036 \\
\hline 14 & 0.079 & 0.062 & 0.036 & 0.010 & 0.006 & 0.981 & 0.190 & 0.113 & 0.065 \\
\hline 28 & 0.157 & 0.094 & 0.044 & 0.011 & 0.009 & 1.279 & 0.284 & 0.165 & 0.106 \\
\hline 60 & 0.547 & 0.181 & 0.068 & 0.013 & 0.013 & 1.366 & 0.380 & 0.262 & 0.149 \\
\hline 90 & 1.229 & 0.318 & 0.082 & 0.014 & 0.014 & 1.618 & 0.513 & 0.334 & 0.209 \\
\hline 120 & $*$ & $*$ & 0.096 & 0.016 & 0.016 & 1.716 & 0.667 & 0.445 & 0.276 \\
\hline 150 & & & 0.110 & 0.017 & 0.018 & 1.822 & 0.908 & 0.569 & 0.372 \\
\hline 180 & & & 0.123 & 0.018 & 0.019 & $*$ & 1.268 & 0.763 & 0.494 \\
\hline 270 & & & 0.168 & 0.019 & 0.019 & & $*$ & 1.825 & $*$ \\
\hline 365 & & & 0.218 & 0.020 & 0.019 & & & * & \\
\hline 545 & & & 0.313 & 0.022 & 0.021 & & & & \\
\hline 730 & 2* & 2* & 0.482 & 0.025 & 0.023 & 2* & 2* & 2* & 2* \\
\hline \multicolumn{10}{|c|}{$\begin{array}{l}\text { * Probetas inmedibles a causa de su curvatura / Unmeasurable specimens because they were very curved. } \\
\text { 2* El mortero original con el que se fabricaron las probetas, estaba totalmente deshecho y dispersado en el seno de su agua de curado / Original } \\
\text { mortar with that the specimens had been manufactured, was totally unmade and dispersed into its water curing. } \\
\text { NOTA /NOTE: Los valores } \Delta \mathbf{L}_{\mathbf{x} \text { dias }}(\%) \text { para el resto de CPO, CPRS y PUZC, fueron publicados años atrás }(5,6)(11) / \Delta \mathbf{L}_{x d a y s}(\%) \text { values for de rest } \\
\text { of OPC, SRPCS and POZC were published years ago }(5,6)(11) \text {. }\end{array}$} \\
\hline
\end{tabular}

contenido de yeso fue más del doble de esa cantidad $(21,0 \%$ $\mathrm{SO}_{3}$, caso del ensayo RT: $\Delta \mathrm{L}$ ) se comportó como agresivo (Tabla 5), y ninguno de estos 30 PUZC ensayados pudo ser considerado de elevada ni moderada resistencia sulfática. Lógicamente en ambos casos, las ettringitas de ambos orígenes estuvieron implicadas en el resultado beneficioso o adverso originado. Por consiguiente, en el primer caso, la cantidad de yeso añadida se puede considerar apropiada para algunos de estos PUZC con MK, hasta el punto de que muchos de ellos podrían ser clasificados, según la norma ASTM C 845-90 (24), como "cementos hidráulicos expansivos". Por el contrario, en cantidades mayores, el yeso se comportó como agresivo. Tanto para los CPO, como para sus correspondientes PUZC con MK, y también, para los PUZC de los CPRS con MK. Y en ambos casos, el beneficioso y el perjudicial, la ettringita de ambos orígenes estuvo implicada.

\section{CONCLUSIONES}

Los valores de $\Delta \mathbf{L}(\%)$ de las probetas tipo ASTM C 45268 y RT: $\Delta \mathrm{L}$ y demás parámetros físicos y químicos determinados, amén de los análisis por SEM y DRX realizados, su discusión e interpretación, han proporcionado las siguientes conclusiones:

1. Mediante el ensayo ASTM C 452-68 -parámetro: $\Delta \mathbf{L}(\%)$ - se ha podido confirmar que al menos, después de las muy pocas horas de hidratación inicial de cada none of the 30 POZCs tested exhibited high nor even moderate sulphate resistance. In the ASTM C 452-68 as well as in the RT: $\Delta L$ test, the ett-rf and ett-If both contributed to the beneficial or adverse effect. Consequently, in the former case, the amount of gypsum added can be regarded to be appropriate for these $M K$-bearing POZCS, many of which may even be classified as "expansive hydraulic cements" as defined in ASTM standard C 84590 (24). On the contrary, higher amounts of gypsum proved to be aggressive in OPCs, their respective $M K$ containing POZCS and MK-bearing POZCS with a SRPC base. In both eases, beneficial and adverso, ettringite from both origins was involved.

\section{CONCLUSIONS}

The conclusions drawn from the $\Delta L(\%)$ findings for the ASTM C 452-68 and RT:AL specimens, the values observed for other physical and chemical parameters, and the SEM and XRD analyses discussed above, are as follows:

1. The ASTM C452-68 (parameter $\Delta L(\%)$ ) test confirmed that at least in the first few hours of initial POZC hydration, the $\mathrm{V}_{f}$ of the ettringite forming from the $\mathrm{Al}_{2} \mathrm{O}_{3}{ }^{r-}$ 
PUZC, la $\mathbf{V}_{\mathbf{f}}$ de la ettringita de la $\mathrm{Al}_{2} \mathrm{O}_{3}{ }^{\mathrm{r}-}$ del $\mathrm{MK}$ que lo constituye, tiene que ser considerablemente mayor que la $\mathbf{V}_{\mathbf{f}}$ de la ettringita del $\mathrm{C}_{3} \mathrm{~A}$ de su correspondiente CPO puro, mientras que su notable menor tamaño, determinado mediante su análisis por SEM y DRX, lo ha verificado.

2. La ett-rf tiene un tamaño mucho más pequeño que la ett-lf, así como unas $\approx 10$ veces menor. Esto es una consecuencia directa de la conclusión 1.

3. Independientemente de ambas conclusiones anteriores, y de acuerdo con las siguientes especificaciones* aplicadas a los resultados que se obtengan de $\Delta \mathbf{L}_{\mathbf{1 4 d}}(\%)$ e $\Delta \mathbf{L}_{\mathbf{2 8 d}}(\%)$ con el método ASTM C 452-68 (2), los 10 $\mathrm{CP}$ y sus 30 PUZC con MK, han sido calificados como sigue:

- de Elevada resistencia sulfática, ERS: el PY-5, PY-1, PY-4 y PY-6;

- de Moderada resistencia sulfática, MRS: el P-5, y

- de Baja resistencia sulfática, BRS: el P-1, P-2, P-4, P-32, P-31 y los 30 PUZC con MK.

Pero si se utilizaran las especificaciones del método $\mathrm{RT}: \Delta \mathrm{L}^{*}$, los 4 anteriores CPRS serían calificados del mismo modo $(5,6)(11)$, los CPO P-5 y P-31 serían calificados de MRS $(5,6)(11)$, y el resto junto con los 30 PUZC con MK, serían calificados del mismo modo también, es decir, de BRS. Finalmente y como consecuencia, se puede decir que para el mismo propósito calificador, el ensayo RT: $\Delta \mathrm{L}$ ha resultado ser algo más preciso que el ASTM C 452-68.

4. De acuerdo con los valores de resistencias mecánicas, estabilidad de volumen y tiempos de fraguado obtenidos, la cantidad de yeso añadida a los 30 PUZC con MK ensayados, no se comportó como agresivo, sino como "regulador de fraguado" (esta conclusión es una consecuencia directa de las conclusiones 1, 2, 4, y 5 de la Parte I (1)). Sin embargo, cuando dicha cantidad de yeso se triplicó, su comportamiento fue claramente como agresivo.

5. De acuerdo con la norma ASTM C 845-90, los PUZC P1/M, P-31/M, P-5/M, PY-5/M, PY-4/M y PY-6/M 80/20, PY-4/M y PY-6/M 70/30 y PY-6/M 60/40, pudieron ser

* (a) Para CP, de la norma ASTM C 150-95 (23): ERS $=\Delta \mathrm{L}_{14 \mathrm{~d}} \leq 0,040 \%$, $\mathrm{y}$

(b) Para CP y también para PUZC, según la propuesta de R. Talero $(5,6)$ y $(11)$ : ERS $=>\Delta \mathrm{L} 28 \mathrm{~d} \leq 0,054 \%$; MRS $=>0,073 \% \leq \Delta \mathrm{L} 28 \mathrm{~d}>0,054 \% ;$ BRS $=>\Delta \mathrm{L} \geq$ $0,073 \%$,

Para CP y para PUZC, según también esta otra propuesta de R. Talero $(5,6)$ y $(11)$ :

ERS: $\Delta L_{28 d} \leq$ 0,044\%; MRS: 0,095\% $\leq \Delta L_{28 d}$ $>0,044 \%$; BRS: $\Delta L_{28 d}>0,095 \%$. furnished by the constituent MK must be substantially higher than the $V_{f}$ of the ettringite from the $C_{3} A$ furnished by the respective pure OPC. These findings were corroborated by SEM and XRD analysis, which verified the much smaller size of the crystals comprising the former.

2. One direct consequence of the preceding conclusion was that the ett-rf crystals were around ten times smaller than ett-If crystals.

3. The ten PCS and their 30 MK-containing POZCs were classified for their resistance to sulphate based on the $\Delta L_{14 d}(\%)$ and $\Delta L_{28 d}(\%)$ values found using the ASTM C 452-68 method (2) and the specifications described below*. On these grounds, the cements studied can be classified as follows:

- high sulphate resistance, HSR: PY-5, PY-1, PY-4 and PY-6:

- moderate sulphate resistance, MSR: P-5; and

- Iow sulphate resistance, LSR: P-1, P-2, P-4, P-32, P-31 and the $30 \mathrm{MK}$-containing POZCs.

Using the RT: $\Delta L$ method, the four preceding SRPCS would be classified as shown (5,6)(11); OPCS P-5 and P31 could be classified as MSR $(5,6),(11)$; and the others, together with the 30 MK-bearing POZCs, would be classified as above, i.e., as LSR. According to the foregoing, the $R T: \Delta L$ test proved to be somewhat more accurate than the ASTM V 452-68 method for the intents and purposes of this classification.

4. According to the mechanical strength, volume stability and setting time values obtained, when small amounts of gypsum were added to the $30 \mathrm{MK}$-containing POZCS tested, the salt acted not aggressively but as a "setting regulator" (this conclusion is a direct consequence of conclusions 1,2,4 and 5 of Part I (1)). When the amount of gypsum was trebled, however, it clearly behaved like an aggressive agent.

5. According to ASTM standard $C 845-90$ criteria, POZCs $P-1 / M, P-31 / M, P-5 / M, P Y-5 / M, P Y-4 / M$ and $P Y-6 / M$ 80/20, $P Y-4 / M$ and $P Y-6 / M$ 70/30 and $P Y-6 / M$ 60/40 may
* (a) For PC, according to standard ASTM C 452-68 (23): $H S R=>\Delta L_{14 d} \leq 0.040 \%$, and

(b) for $P C$ and POZC, according to $R$. Talero's proposal $(5,6)(11): H S R=>\Delta L 28 d \leq 0.054 \% ; M S R=>$ $0.073 \% \leq \Delta L 28 d>0.054 \% ; L S R=>\Delta L \geq 0.073 \%$. For PC and POZC, also pursuant to R. Talero's proposal $(5,6)(11)$ :

$H S R=>\Delta L 28 d \leq 0,044 \% ; M S R:=>0,095 \% \leq$ $\Delta L 28 d>0,044 \% ; L S R=>\Delta L 28 d>0,095 \%$. 
calificados "cementos hydráulicos expansivos" (24), ya que sus valores del $\Delta \mathbf{L}_{\mathbf{7 d}}(\%)$ han estado comprendidos entre $0,04 \%$ y $0,10 \%$ (24), el resto, no. Esta conclusión es también una consecuencia directa de las conclusiones $1,2,4$, y 5 de la Part I (1)) y del primer párrafo de la conclusión anterior. be classified as "expansive hydraulic cements" (24), for their $\Delta L(\%)$ values ranged from 0,04 to $0,10 \%$ (24); none of the other blends met the requirement for such classification. The foregoing is likewise a direct consequence of conclusions 1,2,4 and 5 of Part I (1) as well as of the preceding conclusion.

\section{BIBLIOGRAFÍA / BIBLIOGRAPHY}

(1) Talero, R.: "Kinetic and morphological differentiation of ettringites in plain and blended Portland cements using metakaolin, and the ASTM C 452-68 test: Part I: kinetic differentiation". Mater. Construcc. 292, vol. 58 (2008), pp. 45-68.

(2) ASTM C 452-68 Standard: "Standard Test Method for Potential Expansion of Portland Cement Mortars Exposed to Sulfate". Annual Book of ASTM Standards. Part 9, Cement; Lime; Gypsum (1968), pp. 298-300.

(3) Moya, S.; Sanz, J.; Serratosa, J. M.; Madani, A.; Aza, S.: "Aluminum-27 and Silicon-29 Magic Angle Spinning Nuclear Magnetic Resonance Study of the Kaolinite-Mullite Transformation". J. Am. Ceram. Soc., vol. 71, no 10 (1988), pp. C-418-C-421.

(4) Talero, R.: "Comparative XRD Analysis Ettringite Originating from Pozzolan and from Portland Cement". Cem. Concr. Res., vol. 26, no 8 (1996), pp. 1277-1283. doi: 10.1016/0008-8846(96)00092-0

(5) Talero, R.: "Contribution to the Analytical and Physical-Chemistry Study of the Ternary System: Pozzolanic Cements-Gypsum-Water". Tesis Doctoral. Universidad Complutense de Madrid, Madrid, (1986).

(6) Talero, R.: "Sulfate Resistance of Portland Cements. Accelerated Test to Determine it: Specifications". Monograph no 399, Instituto C.C. "Eduardo Torroja" (1989).

(7) Talero, R.: "Kinetochemical and Morphological Differentiation of Ettringites by the Le Chatelier-Ansttet Test". Cem. Concr. Res., vol. 32 (2002), pp. 707-717. doi: 10.1016/S0008-8846(01)00749-9

(8) Talero, R.: "Performance of the Metakaolin and Portland Cements Forming Ettringite: Kinetic and Morphological Differences". 11th Intern. Congress on the Chemistry of Cement, 11-16 mayo de 2003, Durban, South Africa, vol. 2, pp. 853-867.

(9) Talero, R.: "Kinetochemical and Morphological Differentiation of Ettringites by Metakaolin, Portland Cements and the Le ChatelierAnsttet Test. Parameter: Vicat Needle Penetration". Silicates Industriels, vol. 68, nums. 11-12, nov.-dic. 2003, pp. 137-146.

(10) Talero, R.: "Performance of Metakaolin and Portland Cements in Ettringite Formation as Determined by ASTM C 452-68: Kinetic and Morphological Differences". Cem. Concr. Res., vol. 35 (2005), pp. 1269-1284. doi:10.1016/j.cemconres.2004.10.002

(11) Talero, R.; Bollati, M. R.; Hernández-O., F.: "Manufacturing Non-traditional Mortars and Concretes by OPC, Metakaolin and Gypsum (15.05\%)". Mater. Construcc. 256, vol. 49 (1999), pp. 29-41.

(12) Eitel, W.: "Recent Investigations of the System: Lime-Alumina-Calcium Sulfate-Water and its Importance in Building Research Problems". Journal of Am. Concr. Inst., vol. 28, no 7 (1957), pp. 679-698.

(13) ASTM C 595M-95 Standard: "Standard Specification for Blended Hydraulic Cements". Annual Book of ASTM Standards, Sec. 4 Construction, vol. 04.01, Cement; Lime; Gypsum (1995), pp. 291-296.

(14) EN 196-5 Standard: "Instrucción para la Recepción de Cementos RC-97 (R.D. 776/1997, de 30 de mayo). Pliego de Prescripciones Técnicas Generales para la Recepción de Cementos RC-75 (BOE no 206 de 28 de agosto de 1975)". Frattini, N.: Ann. Chim. Applicata, vol. 39 (1949), pp. 616-620.

(15) EN 196-1:1996 Standard: "Métodos de ensayo de cementos. Parte 1: Determinación de resistencias mecánicas (Mechanical Strengths Determination)". AENOR, Madrid.

(16) EN 196-3:1996 Standard: "Métodos de ensayo de cementos. Parte 3: Determinación del tiempo de fraguado (Setting Times Determination) y estabilidad de volumen (Volume Stability Determination-Le Chatelier's Needles)." AENOR, Madrid.

(17) Von Weimarn, P.; Walton, H. F. (ed.): Principles and Methods of Chemical Analysis, Prentice-Hall, New York (1952), p. 21.

(18) Garrido, J.: Forma y estructura de los cristales, Editorial Alhambra (1973), p. 76.

(19) Talero, R.; Bollati, M. R.: Private Official Report (1990).

(20) Mather, K.: "Factors affecting sulfate resistance of mortars". Proceedings 7th Intern. Congress on the Chemistry of Cement, Paris, vol. 5 (1980), pp. 580-585.

(21) Metha, P. K.: "Effect of Fly Ash Composition on Sulfate Resistance of Cement". J. Am. Concr. Inst., vol. 83, no 6 (1986), pp. 994-1000. (22) Tikalsky, P. J.; Carrasquillo, R. L.: "Influence of Fly Ash on the Sulfate Resistance of Concrete. ACI Journal Materials (ACI Structural Journal), vol. 89, no 1 (1992), pp. 69-75.

(23) ASTM C 150-95 Standard: "Standard Specification for Portland Cement". Annual Book of ASTM Standards. Sec. 4 Construction, vol. 04.01, Cement; Lime; Gypsum (1995), pp.128-132.

(24) ASTM 845-90 Standard: "Standard Specification for Expansive Hydraulic Cement". Annual Book of ASTM Standards. Sec. 4 Construction, vol. 04.01, Cement; Lime; Gypsum (1995), pp. 391-393. 


\section{Fé de errata}

La versión impresa del artículo de R. Talero:

Diferenciación cinética y morfológica de ettringitas mediante metakaolín, cementos Portland y el ensayo ASTM C 452-68. Parte II: diferenciación morfológica mediante análisis por SEM y DRX, Materiales de Construcción Vol. 59, 293, 35-51, enero-marzo 2009. doi: $10.3989 / m c .2009 .30805$

contiene una errata en la leyenda de la figura 6.

\section{Donde la versión impresa dice:}

Figura 6. Ettringita de "rápida" formación.

Figure 6. Rapid forming ettringite (ett-rf).

\section{Debería decir:}

Figura 6. Ettringita de "lenta" formación.

Figure 6. Slow forming ettringite (ett-rf).

La errata figura corregida en esta versión electrónica.

Pedimos disculpas a nuestros lectores.

\section{Corrigendum}

The printed version of the article by R. Talero:

Kinetic and morphological differentiation of ettringites in plain and blended Portland cements with metakaolin and the ASTM C 452-68 test. Part II: Morphological differentiation by SEM and XRD analysis, Materiales de Construcción Vol. 59, 293, 3551, enero-marzo 2009. doi: 10.3989/mc.2009.30805

Contains a misprint in the legend for Figure 6.

Where the printed version reads:

Figura 6. Ettringita de "rápida" formación.

Figure 6. Rapid forming ettringite (ett-rf).

It should read:

Figura 6. Ettringita de "lenta" formación.

Figure 6. Slow forming ettringite (ett-rf).

The misprint is amended in this electronic version. We apologize for any inconvenience to our readers. 